\title{
Larval body patterning and apical organs are conserved in animal evolution
}

\author{
Heather Marlow ${ }^{1 *}$, Maria Antonietta Tosches ${ }^{1}$, Raju Tomer ${ }^{1,2}$, Patrick R Steinmetz ${ }^{1,3}$, Antonella Lauri ${ }^{1,4}$, \\ Tomas Larsson ${ }^{1,5}$ and Detlev Arendt ${ }^{*}$
}

\begin{abstract}
Background: Planktonic ciliated larvae are characteristic for the life cycle of marine invertebrates. Their most prominent feature is the apical organ harboring sensory cells and neurons of largely undetermined function. An elucidation of the relationships between various forms of primary larvae and apical organs is key to understanding the evolution of animal life cycles. These relationships have remained enigmatic due to the scarcity of comparative molecular data.
\end{abstract}

Results: To compare apical organs and larval body patterning, we have studied regionalization of the episphere, the upper hemisphere of the trochophore larva of the marine annelid Platynereis dumerilii. We examined the spatial distribution of transcription factors and of Wht signaling components previously implicated in anterior neural development. Pharmacological activation of Wnt signaling with Gsk3 $\beta$ antagonists abolishes expression of apical markers, consistent with a repressive role of Wnt signaling in the specification of apical tissue. We refer to this Wnt-sensitive, six3- and foxq2-expressing part of the episphere as the 'apical plate'. We also unraveled a molecular signature of the apical organ - devoid of six 3 but expressing foxj, irx, nkx3 and hox - that is shared with other marine phyla including cnidarians. Finally, we characterized the cell types that form part of the apical organ by profiling by image registration, which allows parallel expression profiling of multiple cells. Besides the hox-expressing apical tuft cells, this revealed the presence of putative light- and mechanosensory as well as multiple peptidergic cell types that we compared to apical organ cell types of other animal phyla.

Conclusions: The similar formation of a six3+, foxq2+ apical plate, sensitive to Wnt activity and with an apical tuft in its six3-free center, is most parsimoniously explained by evolutionary conservation. We propose that a simple apical organ - comprising an apical tuft and a basal plexus innervated by sensory-neurosecretory apical plate cells - was present in the last common ancestors of cnidarians and bilaterians. One of its ancient functions would have been the control of metamorphosis. Various types of apical plate cells would then have subsequently been added to the apical organ in the divergent bilaterian lineages. Our findings support an ancient and common origin of primary ciliated larvae.

Keywords: Apical-blastoporal axis, Apical organ, Body plan, Larval evolution

\section{Background}

The vast majority of animal phyla live in the ocean and develop via small ciliated larvae that form part of the zooplankton [1]. These larvae, called 'primary larvae', are equipped with sensory cells to perceive various stimuli including light, touch and chemical cues [2,3]. Simple nervous systems integrate sensory information and control

\footnotetext{
* Correspondence: Heather.Marlow@embl.de; Detlev.Arendt@embl.de ${ }^{1}$ European Molecular Biology Laboratory, Development Biology Unit, EMBL Heidelberg, Meyerhofstraße 1, 69117 Heidelberg, Germany

Full list of author information is available at the end of the article
}

ciliary locomotion [4]. Most conspicuously, an 'apical organ' is found in various groups, including cnidarians [5], protostome annelids, mollusks [2], flatworms [6] and nemertines [7], as well as deuterostome echinoderms [8] and hemichordates [9]. These groups belong to the Neuralia (which includes cnidarians and bilaterian protostomes and deuterostomes; Figure 1) [10]. Apical organs are often equipped with an 'apical tuft' of long cilia and include a small set of sensory-neurosecretory cell types $[11,12]$. As shown for cnidarians, mollusks and annelids, apical organs play a role in the control of settlement 


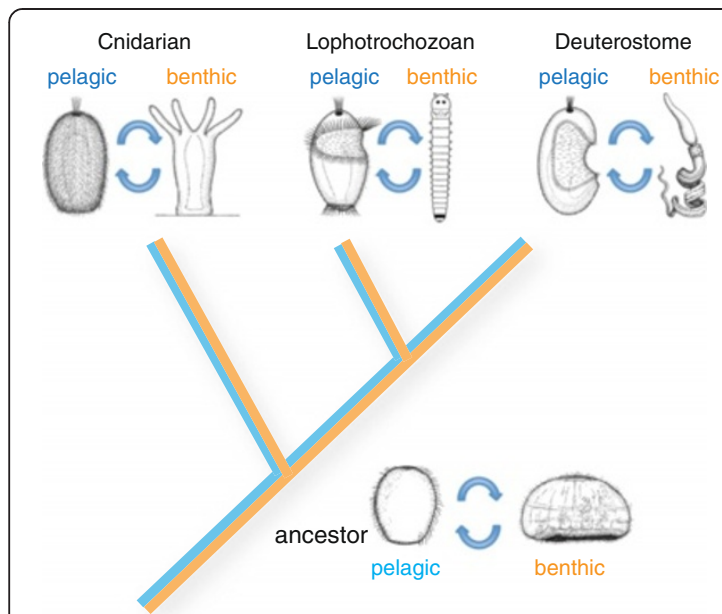

A Pelago-benthic neuralian ancestors: Single terminal addition of benthic adult stages (Jägersten 1972; Arendt et. al, 2013)
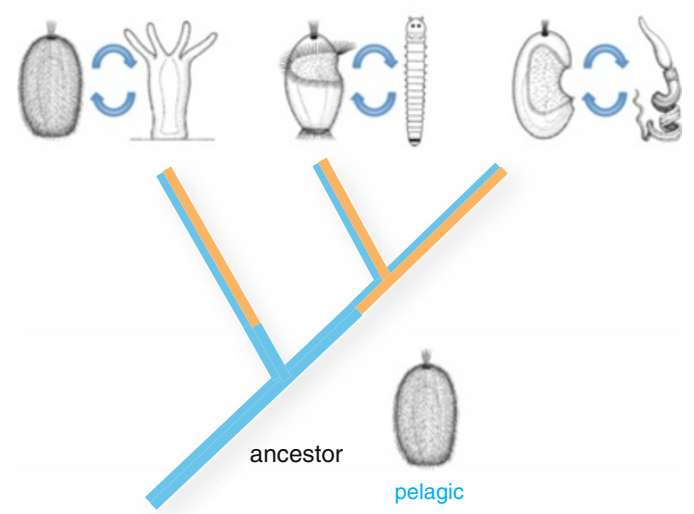

B Holopelagic neuralian ancestors.: Terminal addition of benthic adult benthic stages two (or three) times (Nielsen 2012)

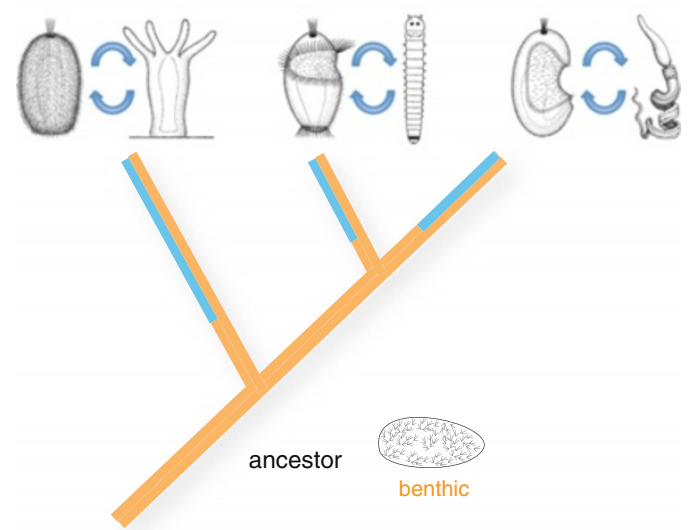

C Holobenthic neuralian ancestors: Repeated intercalation of swimming larval stages; many times in each lineage (Raff 2008)
Figure 1 The three scenarios show the origin of the pelagic larval body plan, indicated by red arrows. The presence of pelagic forms is indicated by blue lines and that of benthic forms by brown lines. A single-coloured line indicates a monophasic life cycle that would be pelagic in scenario B and benthic in scenario $C$. Double lines (blue and brown) indicate a biphasic, pelago-benthic life cycle (with pelagic larval and benthic adult forms). Note that the biphasic life cycle is assumed to have evolved multiple times independently in scenario C. (A) The classical view implies homology of both ciliated larvae and benthic adults that, once evolved, have remained part of the eumetazoan life cycle [17]. (B) Nielsen [16] modified this view to propose that the holopelagic neuralian ancestors persisted beyond the initial divergence of the major neuralian clades, and that the biphasic life cycle with benthic adults arose independently in the cnidarians and once or twice in the bilaterians. (C) In stark contrast, other authors assume that today's ciliated larvae arose convergently many times by the repeated intercalation of a pelagic dispersal larva into primarily monophasic, holobenthic life cycles and are thus evolutionarily unrelated. This view implies that the characteristics of today's swimming larvae such as apical organs and equatorial ciliary bands evolved convergently [18].

[13-15], facilitating the integration of multimodal sensory input and the coordination of effector cells. Development involving primary larvae (or any other kind of secondary larvae) is referred to as 'indirect'; if it does not involve a larval stage, it is referred to as 'direct' [16].

Widespread occurrence of ciliated larvae, with similar overall body plans, has prompted radically different views regarding their evolutionary significance $[16,18-20]$. While some authors consider them an ancient feature of the metazoan life cycle $[16,17,19]$, others assume that they evolved multiple times independently [18,20] (Figure 1). In the past two decades, studies of developmental genes involved in setting up the larval body plan have started to provide a new source of comparative data to resolve these conflicting views. These studies have revealed specific similarities such as the expression of the goosecoid and brachyury genes in foregut, midline and hindgut of lophotrochozoan and deuterostome larvae [21] (in a manner distinct from direct developers such as insects or vertebrates). Also, the ciliary bands characteristic for swimming larvae were found to specifically express otx and three conserved microRNAs in lophotrochozoans and deuterostomes, corroborating the homology of shared larval features [22,23]. Conversely, dissimilar expression reported for $n k 2.1$ and $h n f 6$ in the apical plate of sea urchins and the episphere of abalone larvae [24] raised doubt regarding the common origin of similar shared larval features. However, these pioneering studies thus far relied on small gene sets.

More recently, an extended set of transcription factors has been shown to play a conserved role in patterning the larval body plan in hemichordate [25] and in sea urchin [26,27], belonging to the deuterostomes, and in the sea anemone Nematostella vectensis, a cnidarian 
[28]. These factors respond to the differential stabilization of $\beta$-catenin along the primary body axis, triggered by Wnt signaling $[28,29]$. In particular, six3 and foxq 2 have been shown to negatively respond to Wnt signaling in a complex sequence of patterning events $[28,29]$. These factors specify apical territory around the apical pole [27,30]. For the first time, the conserved regional expression of similar sets of transcription factors provides a molecular framework for the comparison of larval cell types and tissues and thus important clues to larval body plan and apical organ evolution.

In our current study, we investigated the apical patterning system in the marine annelid Platynereis dumerilii [31], a lophotrochozoan protostome with a canonical biphasic pelago-benthic life cycle (involving a pelagic phase, that is, swimming, primary larvae, and a benthic phase, that is, bottom-dwelling adults). We examined the set of transcription factors involved in apical patterning, including six 3 and foxq2, in the episphere of the Platynereis trochophore larva and have shown that, as in deuterostomes and cnidarians, expression of these factors is sensitive to Wnt signaling. We found that the apical organ develops in a small central territory devoid of six 3 expression, that instead expresses a number of other factors, many of which are found in the same location in other neuralians. By expression profiling, we molecularly characterized several cell types that form part of the apical organ in Platynereis, which we compared to apical organ cell types described for other animal groups.

Our results reveal that the larvae of cnidarians, protostomes and deuterostomes exhibit extensive similarity in the molecular topography of body regions around the apical organ, which we use to genetically define 'apical plate' and 'apical organ'; the specification of these regions by a conserved apical signaling system; and the molecular fingerprint of a subset of apical organ cell types. These findings support homology of some primitive type of apical organ (and thus of swimming ciliated larvae) in Neuralia and are most consistent with an early and unique origin of animal larval forms (Figure 1A,B).

\section{Results}

\section{Molecular topography of the apical region}

In the sea urchin [26,27], the hemichordate Saccoglossus kowalevskii [25] and the anthozoan cnidarian Nematostella $[28,30]$, expression of the transcription factors six3 and foxq 2 demarcates the most apical body region. In Saccoglossus and Nematostella, the six3+, foxq2+ domain is peripherally overlapping with a ring of $r x$ and bounded by even more peripheral rings of otx and otp expression [25,28]. Likewise, $f e z f$ is expressed in the apical plate in sea urchin [32] and the hemichordate [33]. We have previously shown that six 3 is expressed in a large contiguous domain of the Platynereis episphere [34], peripherally overlapping with the expression of $r x$ [35].

Building on this, we set out to further refine the molecular topography of the Platynereis larval episphere. We found that, in Platynereis, the newly characterized foxq2 expression demarcated the 'upper' two thirds of the episphere (Figure 2A), largely overlapping with that of six3 (Figure 2B). We refer to this six $3+$, foxq $2+$ region as apical plate, in accordance with classical nomenclature for spiralian trochophore larvae (for example, see [2] and discussion). Expression of the newly characterized fezf (Figure 2C) and that of $r x$ (Figure 2D) overlapped that of six 3 and foxq2 peripherally (with $r x$ being largely restricted to the dorsal and fezf to the ventral body sides). More peripherally, in the 'lower' third of the episphere, we detected expression of otx (Figure 2E) [21], partially overlapping with that of $r x$ dorsally and that of fezf ventrally. Even more peripherally, expression of the otp gene (Figure 2G) [12] demarcated the ciliary band, called the prototroch.

The Platynereis episphere can thus be subdivided into a sequence of molecular regions, arranged in concentric rings from apical to peripheral (Figure 3). This overall sequence matches the molecular topography observed in deuterostomes and cnidarians (Figure 3). Another conserved feature of apical patterning in sea urchin [24,36], Saccoglossus [25] and again in Platynereis [12] is expression of $n k 2.1$ in an apical-ventral territory (Figure 2F), overlapping six3. In sea urchin, this domain includes cells positive for onecut (HNF6) [24], and we found that, in Platynereis, expression of the same genes covers cells located ventromedially at a similar distance to the apical tuft cells (demarcated by a yellow dotted line in the confocal reflection microscopy panels; compare Figure 2F" with Figure 2J'), which indicates co-expression. This is important because the two genes were shown to comprise non-overlapping domains in the apical region of the red abalone Haliotis (where onecut is expressed dorsal to the apical organ only [24]; note that Platynereis also shows dorsal patches of onecut expression in Figure 2J').

The Platynereis trochophore also shares expression features with cnidarian and deuterostome larvae specific to the developing apical organ. In sea urchin [37], Nematostella and Platynereis, the apical tuft and a girdle of cells surrounding the tuft are devoid of six 3 expression (white dashed line in Figure 2B' and compare to Figure 3 in Poustka et al. [37] and Figure 3d in Marlow et al. [28]). In Platynereis, the six3-free region extends into a dorsal patch of cells that becomes separated from the central patch by a band of six $3+$ cells (which includes the conspicuous crescent cells, see below). Inside the six3-free region, we detect restricted expression of several transcription factors (using the nuclei of the two apical tuft cells for reference; yellow circles in confocal apical views in Figure 2): otp (Figure 2G"; in addition to its ring- 


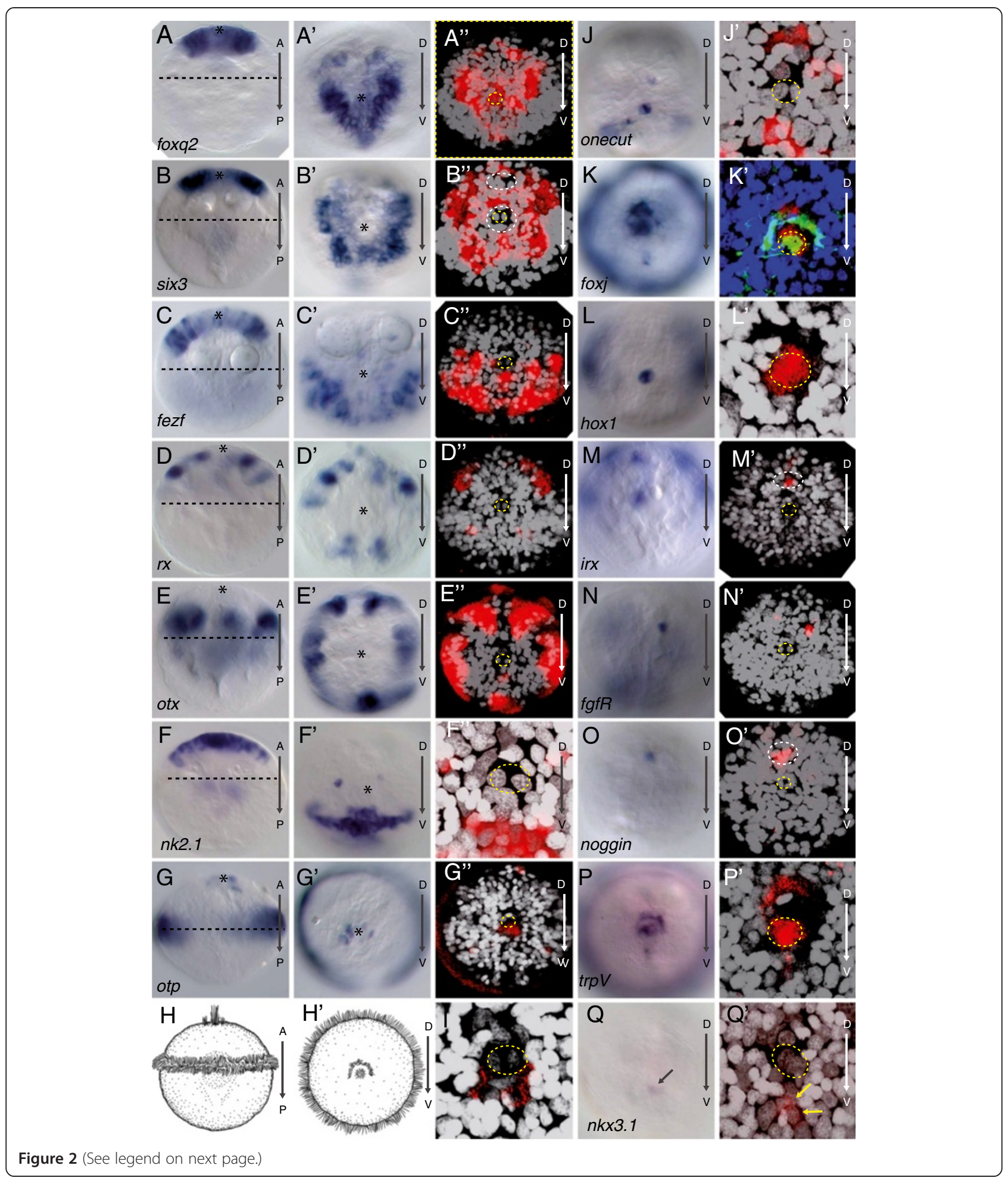


(See figure on previous page.)

Figure 2 Apical regional patterning mRNA expression in early trochophore larvae. (A-G) are ventral views, (A'-G') and (J-Q) are apical views, and $\left(\mathbf{A}^{\prime \prime}-\mathbf{G}^{\prime \prime}\right)$ and $\left(\mathbf{J}^{\prime}-\mathbf{Q}^{\prime}\right)$ are apical views using confocal reflection microscopy of NBT/BCIP staining (red) following in situ mRNA and fluorescent DAPI staining of nuclei (white), allowing localization of individual cells in the apical Plate. $F^{\prime \prime}, I^{\prime}, J^{\prime}, K^{\prime}, L^{\prime}, P^{\prime}$ and $Q^{\prime}$ are high magnification apical views. Ampullary cells are demarcated with yellow dashed circle. All images are of 24 hour post-fertilization (hpf) embryos, except C, C', D, $D^{\prime}, E, E^{\prime}, G, G^{\prime}, L, M, O, O^{\prime}$, which are of 20 hpf embryos. Asterisks mark the tip of the apical pole. (A) Broad apical expression of foxq2 in 24 hpf trochophores. (B) Broad apical expression of six3, excluding area encompassing apical organ and a dorsal patch of cells (demarcated with white dashed lines). (C) Fezf ventrally in apical plate. (D) $R x$ in dorsal and ventral domains between the six 3 domain and the prototroch. (E) Otx in

ring-like domain adjacent to prototroch. (F) Nk2.1 in a ventral strip of cells and in two spots flanking the crescent cells. (G, I) Otp in apical cluster and in prototroch. $\left(\mathbf{H}, \mathbf{H}^{\prime}\right)$ Schematized ventral and apical views at $24 \mathrm{hpf}$ depicting crescent and ampullary cells and prototroch. (J) Onecut in crescent cells and in cells ventral to the ampullary cells. (K) FoxJ in the ampullary cells, crescent cells and prototroch. (K') Antibody staining to acetylated tubulin (green) and DAPI-labeled nuclei (blue). (L) Hox1 in ampullary cells. (M) Irx in six3-negative territory and in an equatorial ring below the prototroch. (N) FgfR in a cell dorsal to the ampullary cells. (O) Noggin in a cell dorsal to the ampullary cells. (P) trpV in cells ventral to the ampullary cells. (Q) Nkx3 in a small patch of cells ventral to the ampullary cells. (Q') Nkx3 in mechanoreceptor cells (yellow arrows).

like expression, see above), nkx3 (Figure 2Q'), foxj (Figure $2 \mathrm{~K}^{\prime}$ ) and hox 1 (Figure 2L'). In addition, the irx gene is expressed in the dorsal patch of cells devoid of six3 expression (Figure 2M'). Notably, $n k x 3$ [28], foxj [30], the hox gene paralog anthox1 [28] and irx [28] are also expressed in the apical region devoid of six3 in Nematostella; foxj matches the region devoid of six 3 expression in sea urchin [38] and apical irx expression has been documented in hemichordates, although broader than in annelids [25]. An apical region devoid of six3 expression, 'filled' by the restricted expression of foxj, $n k x 3$, hox and $i r x$, thus represents a larval-specific transcription factor signature that molecularly defines the apical organ in several distinct, phylogenetically remote neuralian groups such as anemone and annelid (Figure 3) and lends strong support to its evolutionary conservation (see Discussion).

Functional studies have demonstrated the role of fibroblast growth factor (Fgf), transforming growth factor
(Tgf $\beta$ and Fgf signaling) and Wnt signaling in apical plate patterning. For example, Fgf signaling controls formation of the apical organ in sea anemone [14]; the apical plate of sea urchins is patterned by Tgf $\beta$ signaling [39] and $f g f r 1$ localizes to the apical plate during apical organ formation [37]. Similarly, the Platynereis apical organ region showed specific expression of $f g f r$ in a highly restricted population of cells (Figure $2 \mathrm{~N}$ ). We also found an apically restricted domain of the Tgf $\beta$ signaling antagonist noggin in cells devoid of six3 expression (white dashed line in Figure 20'), which indicates that both signaling systems also play a role in apical patterning in Platynereis. Notably, expression of noggin has also been reported for the six3free apical organ in sea anemone [40]. Consistent with a prominent role of Wnt signaling in Platynereis apical patterning, we detected the Wnt receptor molecule frizzled5/ 8 in a broad apical domain (Figure 4A; as seen in the hemichordate Ptychodera [41] and sea urchin [42]) and
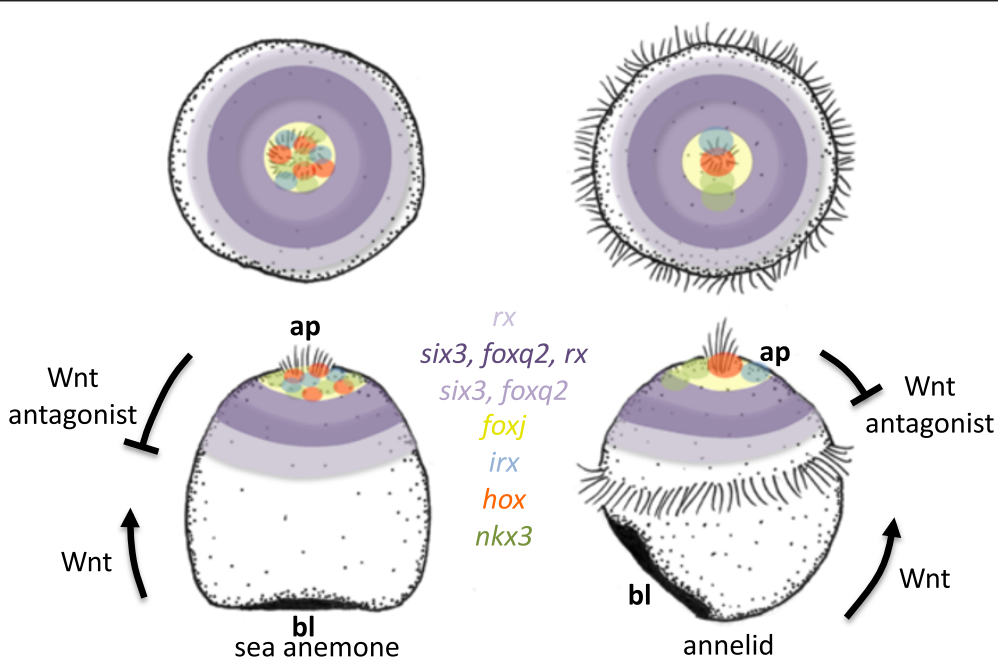

Figure 3 Comparison of apical molecular territories in a sea anemone planula larva and an annelid trochophore. Apical (above) and lateral (below) views of a schematized planula larva of a sea anemone (left panel). Gene expression based on published data for Nematostella vectensis (for references see text). Apical (above) and lateral (below) views of a schematized annelid trochophore larva (right panel). Gene expression based on our data. 

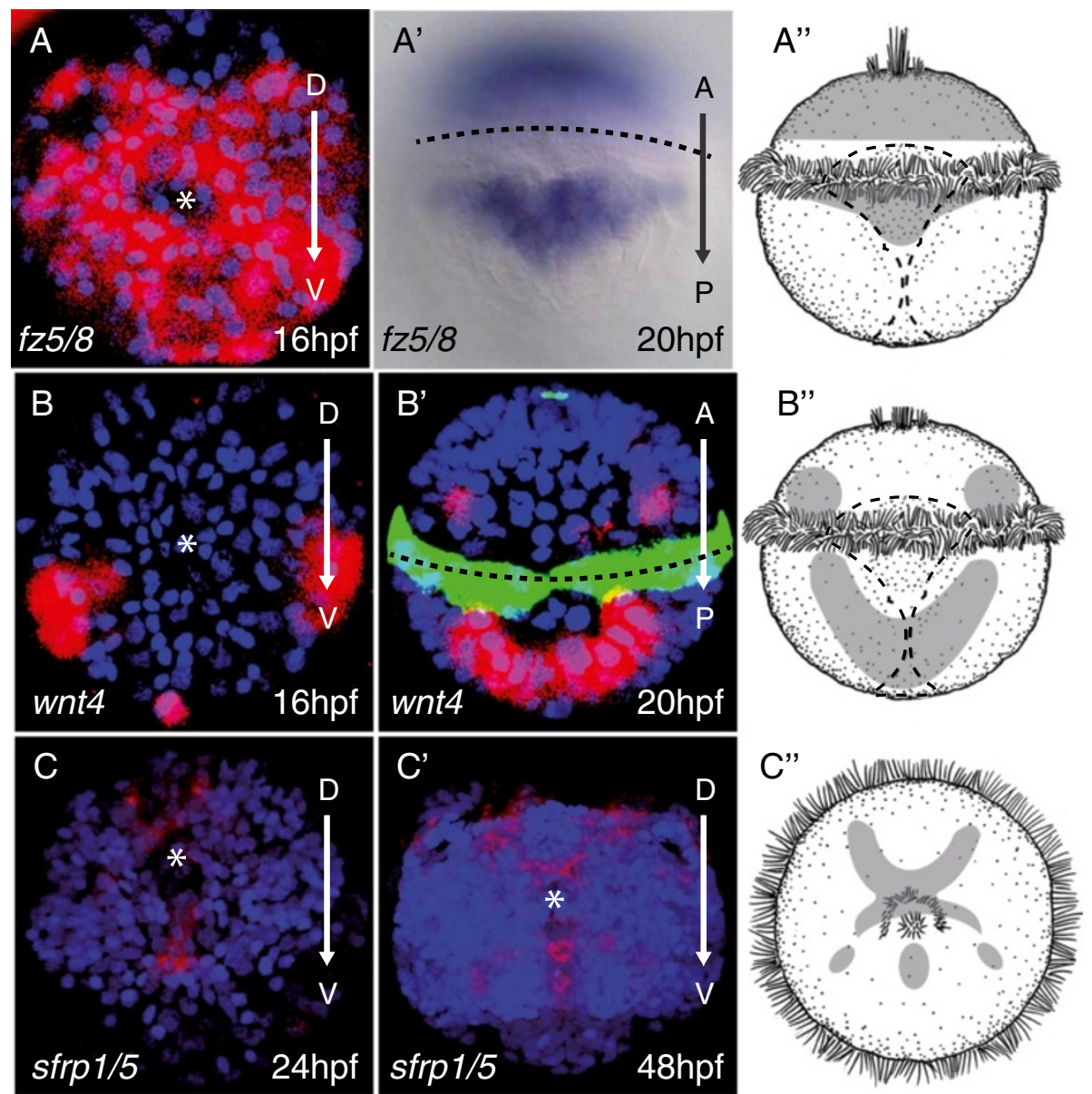

Figure $4 \mathrm{Wnt}$ pathway members are expressed in the episphere and hyposphere during early development. The prototroch is marked with a dashed line. The tip of the apical plate is marked with an asterisk. Arrows indicate dorsal (D), ventral $(V)$, anterior (A) and posterior (P). (A) Frizzled5/8 across the apical plate, 16 hours post-fertilization (hpf) apical view and a (A') 20 hpf ventral view (inset shows a surface ventral view). (B) Wnt4 along the blastopore, 16 hpf lateral view. (B') Confocal image of ventral view of Wnt4 expression in which antibody staining to acetylated tubulin is visible with a green secondary antibody, reflection signal of in situ hybridization is red and nuclei are visible, stained with

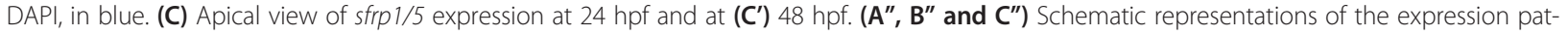
terns in $(\mathbf{A})$ and $(\mathbf{B})$ and $(\mathbf{C})$ and $\left(\mathbf{A}^{\prime}\right)$ and $\left(\mathbf{B}^{\prime}\right)$ and $\left(\mathbf{C}^{\prime}\right)$.

sfrp, which plays a conserved role in antagonizing Wnt signaling in deuterostomes [42,43], specifically in the apical organ region (Figure 4C,C',C"). Furthermore, we detected early expression of wht4 in ventral peripheral episphere regions, outside of (but abutting) the six 3 domain, consistent with a role in apical patterning (Figure 4B,B'). Wnt4 is one example of a Wnt paralog expressed at the right stage and location in developing Nematostella [44] and amphioxus [45] to be involved in patterning along the primary axis; yet, in the absence of specific knockdown or knockout data, no case for the specific involvement of Wnt4 can be made. Note that none of the many Wnts expressed in Platynereis larvae $[46,47]$ appears to be expressed in the six3+ apical plate, in line with repression of Wnt signaling being a prerequisite for apical specification to occur, a notion that we set out to test further experimentally.
Ectopic Wnt signaling abolishes specification of the apical organ region

In deuterostome larvae such as sea urchin and Saccoglossus, as well as in the cnidarian Nematostella, the expression of apical markers such as foxq 2 and six 3 critically depends on levels of active Wnt signaling $[27,43,48]$. Activation of canonical Wnt signaling via chemical inhibition of Gsk3 $\beta$ via $\mathrm{Li}+$ and/or paullone treatment in sea urchins [37], hemichordates [43] and cnidarians [28] results in the loss of apical ectodermal markers. Conversely, degradation of nuclear $\beta$-catenin in sea urchin leads to expansion of apical ectodermal genes including $n k 2.1$, foxq2, six $3, r x$ and $f g f R$ [27], indicating that Wnt-mediated antagonism of apical plate markers plays a role in the development of apical territories in deuterostome and cnidarian larvae. To test the role of Wnt signaling in apical patterning in Platynereis larvae, we exposed early trochophores to 


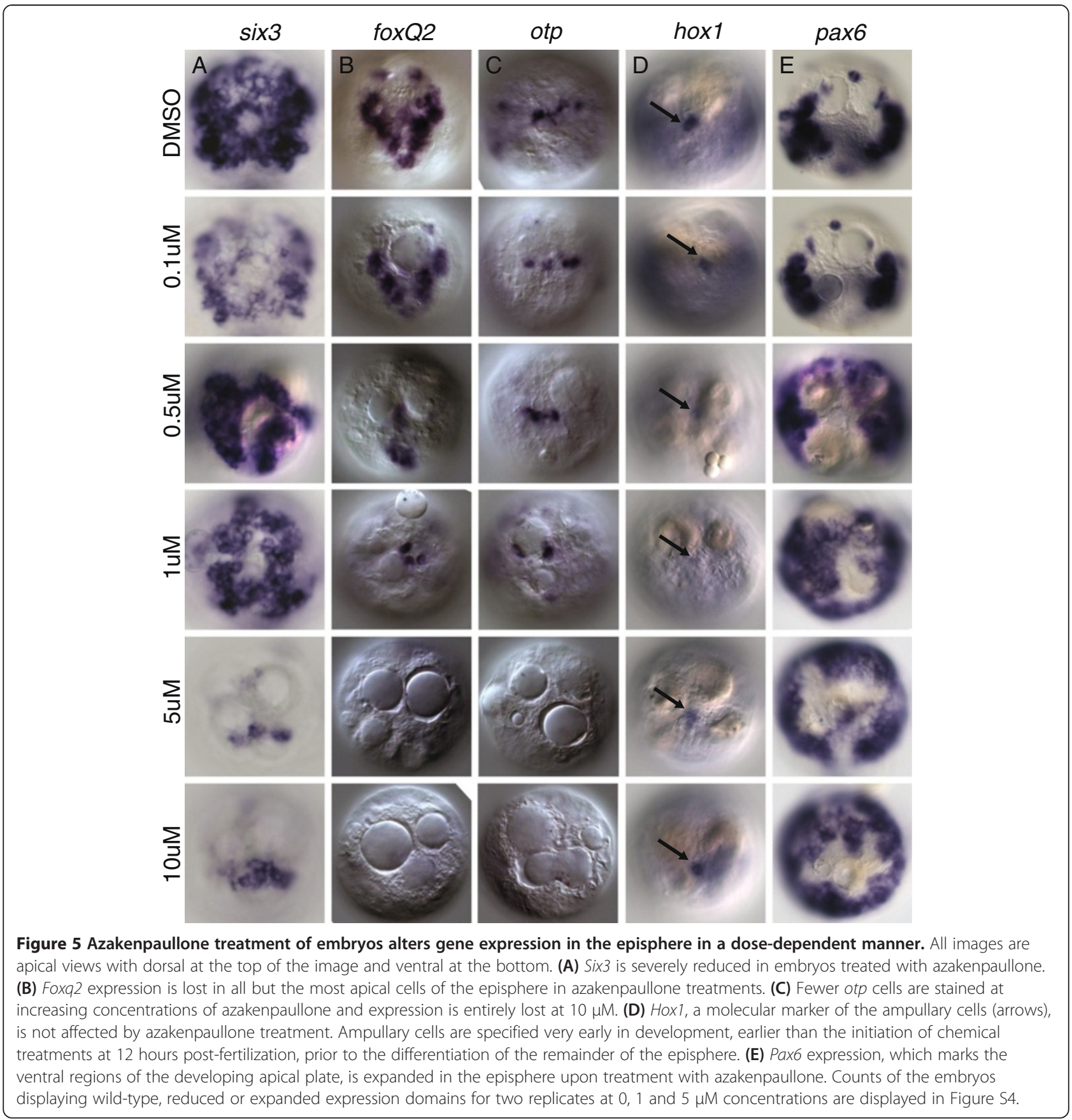

azakenpaullone, a selective inhibitor of Gsk3 $\beta$ [49] that has been shown to trigger nuclear $\beta$-catenin accumulation in Platynereis, mimicking ectopic activation of Wnt signaling $[47,50]$. We found that azakenpaullone specifically knocked down or abolished apical expression of episphere markers, including the broadly expressed six3 (Figure 5A) and foxq 2 (Figure 5B) in a concentration-dependent manner, with the majority of expression reduced or lost between $1 \mu \mathrm{M}$ and $5 \mu \mathrm{M}$ (Figure 5). Conversely, the expression of pax6, which occupies a more ventral peripheral position in the larval episphere [51] (overlapping with
Wnt4; Figure 4E), was expanded at $0.5 \mu \mathrm{M}$ to $10 \mu \mathrm{M}$ concentrations of azakenpaullone (Figure 5E). The number of $o t p+$ apical organ cells was also reduced at higher concentrations of azakenpaullone (Figure 5C), with all cells absent at 5 and $10 \mu \mathrm{M}$ concentrations. By contrast, the expression of hox 1 in the apical tuft cells persisted at all concentrations (Figure 5D, arrows). This may have been because tuft cells are among the first cells to differentiate in the apical plate (Figure 6A). To test the dynamic role of Wnt signaling in episphere patterning, we conducted washout experiments in 


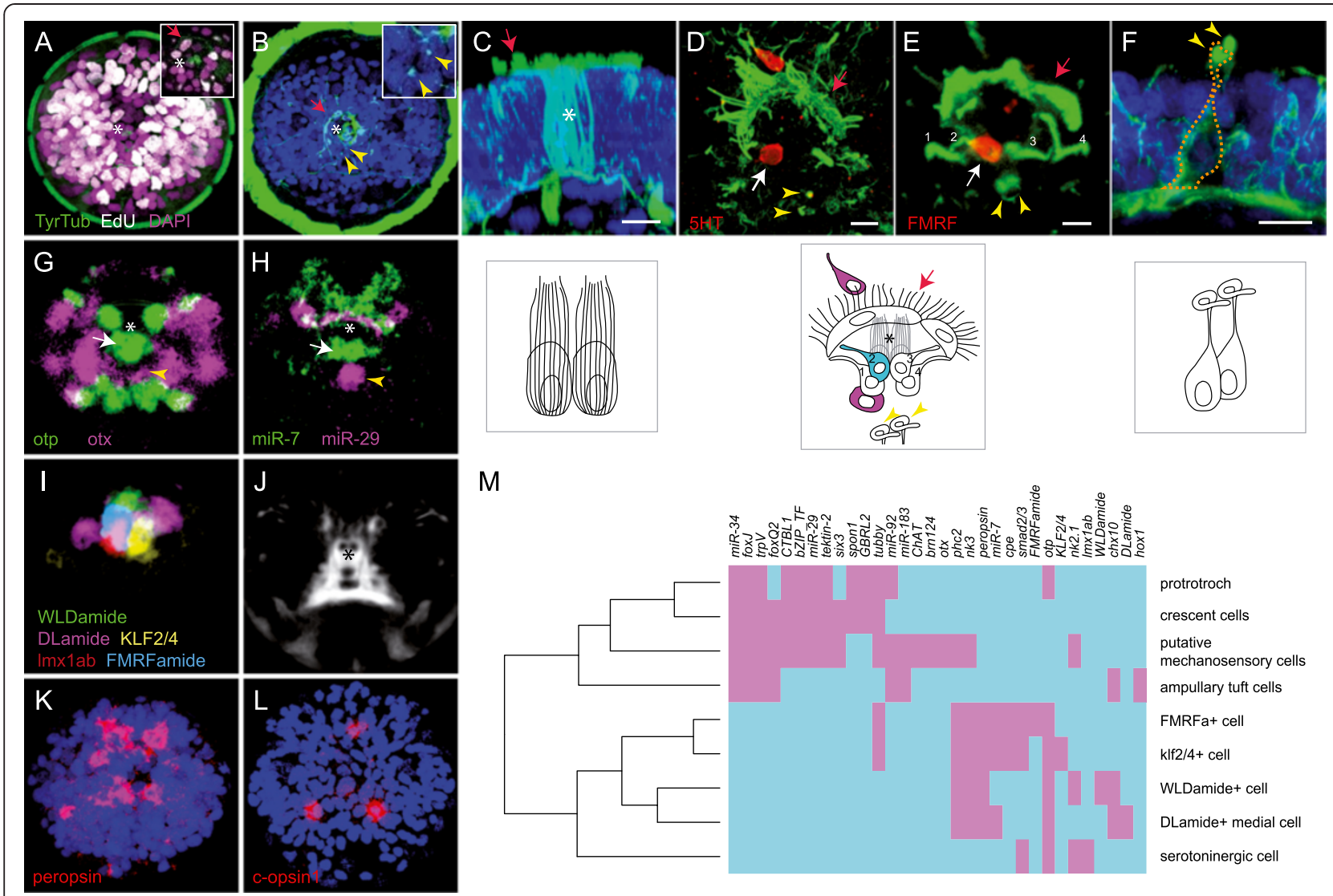

Figure 6 Molecular fingerprint of Platynereis apical organ cell types. (A) EdU incorporation (white) in dividing cells between 22 and 24 hours post-fertilization (hpf) (apical view). Central EdU-negative cells (magenta) represent post-mitotic apical organ cells. Inset: 5 um zprojection of apical organ. (B) Acetylated tubulin staining at $30 \mathrm{hpf}$, apical view. Crescent cells located dorsal to ampullary tuft cells. Inset: Cilia of the putative mechanosensory cells (arrowhead). (C) Lateral view of ampullary tuft cells, acetylated tubulin (green) and DAPI staining (blue), 30 hpf. (D) Serotoninergic cells of the apical organ stained with an anti-5HT antibody, $48 \mathrm{hpf}$. White arrow indicates serotonergic interneuron (magenta in schematic). (E) Four otp + peptidergic flask-shaped cell (numbers) at $48 \mathrm{hpf}$ (apical view). One of these labeled by an FMRFamide antibody. In schematic, numbers indicate otp + cells and the FMRFamidergic cell is in cyan. (F) Lateral view of putative mechanosensory cells, 48 hpf (arrowheads: stiff curly tips of the sensory cilia). (G, H) Mutually exclusive gene expression at $48 \mathrm{hpf}, 23 \mu \mathrm{m}$ z-projection of averaged expression patterns obtained with profiling by image registration (PrImR). (I) Cell types of the otp + domain. The image shows non-overlapping expression of markers of each cell as deduced from PrlmR, $11 \mu \mathrm{m}$ z-projection of average expression patterns. (J) $4 \mu \mathrm{m}$ z-projection of the average axonal scaffold at 48 hpf, showing the deep position of the two ampullary cells surrounded by neuropil. (K) Expression of peropsin at 24 hpf (L) Expression of c-opsin1 at 20 hpf. (M) Hierarchical clustering of the molecular fingerprint of individual cell types identified within the apical organ region and of the prototroch for comparison. Expression in magenta. Asterisk indicates the two ampullary tuft cells, red arrows indicate crescent cells and yellow arrowheads indicate cilia of two putative mechanosensory cells. In panels B-H, gene expression is in red, DAPI staining in blue and tubulin staining in green unless otherwise specified. Panels C-F, scale bar is $10 \mu \mathrm{m}$.

azakenpaullone-treated embryos (Additional file 1: Figure S3). Following washout at 24 hours, embryos were assessed at 30 hours post-fertilization (hpf) for recovery of gene expression. We saw moderate recovery in the expression of foxq 2 and six 3 as well as a slight restriction of pax6, but no change in the number and location of $o t p+$ cells. We attribute the moderate recovery in expression to the determinate lineage of Platynereis larvae, in which stereotyped divisions may result in a restricted fate potential very early in development. Taken together, our data indicate that in Platynereis as in deuterostome larvae, the transcription factors defining the molecular identity of apical body regions, of which six 3 and foxq 2 form core components, are opposed by a Wntdependent signaling center.

\section{Morphological and molecular characterization of apical organ cell types}

Light and electron optic studies have revealed cell types that make up the apical organs of different invertebrate larval groups [11,52-54]. In Platynereis, the apical tuft was visible by $16 \mathrm{hpf}$ (cf. $\operatorname{trp} V$ channel expression at 24 hpf, Figure $2 \mathrm{P}$ ) and other apical organ cells were likewise post-mitotic by $24 \mathrm{hpf}$ (Figure 6A), expressing markers indicative of neuronal differentiation. At $30 \mathrm{hpf}$, several apical cell types were fully morphologically differentiated 
(Figure 6B; [31]). We found that the apical tuft was formed by two basket-shaped cells with intracellular tubulin support structures (Figure 6C); cells with a very similar morphology, referred to as ampullary cells, have previously been described in mollusk larvae [11]. These cells persisted deep in the medial brain at later stages in the center of a massive commissural and neurosecretory neuropil (Figure 6J), and may thus represent a structural organizing center for the juvenile nervous system, as suggested for other polychaete larvae [50]. Dorsal to the ampullary tuft cells, we found another set of large cells with multiple motile cilia in a crescent-moon shape, known as crescent cells (Figure 6D). Two serotonergic cells have also been found in the apical organ region by $30 \mathrm{hpf}$ [31]. Closest to the tuft was a serotonergic interneuron (white arrow, Figure 6D) lacking sensory dendrites. This cell was located deep in the epithelium, adjacent to an assembly of previously described sensoryneurosecretory flask-shaped cells (Figure 6E) that, morphologically, resemble chemosensory cells [12] (called parampullary cells in mollusks [11]). More ventral to the parampullary cells, we detected a median pair of cells bearing short, stiff and curly sensory cilia resembling mechanoreceptors (Figure 6F).

These distinctive morphologies, in conjunction with the recently established Profiling by Image Registration (PrImR) technique, enabled us to assign a molecular fingerprint to these cells, providing them with unique molecular identities [47]. PrImR utilizes the stereotyped development of the Platynereis axonal scaffold to generate in silico alignments of mRNA in situ expression patterns, and allows single cell co-expression analyses to be conducted [47]. Of a collection of 140 genes currently available for PrImR single cell co-expression analysis, 29 were differentially expressed in cells of the apical organ region in the $48 \mathrm{hpf}$ larva. Additional file 1: Figure S5 details the PrImR-based co-expression analysis for the above-mentioned morphologically identifiable cells, namely the ventral-most serotoninergic cell (Additional file 1: Figure S5A), the parampullary sensory-neurosecretory cells (Additional file 1: Figure S5B-E), the ampullary tuft cell (Additional file 1: Figure S4F), the crescent cells (Additional file 1: Figure S5G) and the pair of putative mechanoreceptors (Additional file 1: Figure $\mathrm{S} 5 \mathrm{H}$ ).

PrImR revealed unique sets of genes expressed by each of these cell types, in line with their specialized sensoryneurosecretory and neuronal characteristics. For example, as determined previously, the flask-shaped parampullary cells expresses otp (Figure 6G; Additional file 1: Figure S5B-E; and see above), mir-7 (Figure $6 \mathrm{H}$ ) and prohormone convertase 2 (phc2) [12]. Beyond that, PrImR allowed cellular allocation of transcripts encoding neuropeptide precursors for DLamide, FMRFamide and WLDamide (Figure 6I), consistent with a conserved role of otp in specifying different types of peptidergic cells [12]. These three neuropeptides mediate opposing effects on locomotor behavior with DLamide and FMRFamide exposure leading to an increase and WLDamide leading to a decrease in ciliary beating frequency [55]. The otp + peptidergic cells also expressed MIP, the recently described settlement-inducing neuropeptide [15]. In addition, we found that all $o t p+$ sensory-neurosecretory cells were positive for the newly identified peropsin gene (Figure 6K), an opsin-related photopigment that may function as photopigment or photoisomerase [56], indicating that these cells (or adjacent cells) are light-sensitive. Complementing this, we observed that the previously characterized c-opsin1 [35], an ortholog of rhodopsin and other c-opsins, was expressed in cells around the apical organ (Figure 6L). As c-opsin1 expression is difficult to score in 48 hpf larvae (the stage for which the PrImR resource is available), we were not able to further characterize the $c$ $o p \sin 1+$ cells. One of the $o t p+$ cells was demarcated by the expression of $\operatorname{lm} x 1 a b$ (a terminal selector gene for serotoninergic neurons [57]) and by position correlates to the serotonergic interneuron (Additional file 1: Figure S5A; Figure 6I). The ampullary apical tuft cells (Additional file 1: Figure S4F) specifically expressed hox1 (Figure 2L) and a trpV channel previously implicated to serve mechanosensory roles in other protostomes (Figure 2P) [58], indicative of multiple sensory modalities. Finally, and consistent with their specialized morphology, the two putative mechanosensory cells (Additional file 1: Figure $\mathrm{S} 5 \mathrm{H}$ ) expressed miR-183 (Additional file 1: Figure S1), a conserved microRNA that demarcates chemo- and mechanosensory cells across bilaterians [22,59,60]. Furthermore, they were the only cells to express otx (compare Figure 2E’).

\section{Hierarchical clustering reveals distinct groups of apical organ cells}

In line with our observation that at $24 \mathrm{hpf}$ the apical organ region including the tuft cells was devoid of six3 expression, the tuft cells themselves and the directly ventrally adjacent sensory-neurosecretory and serotoninergic cells were six3-negative at $48 \mathrm{hpf}$. By contrast, the crescent and mechanoreceptor cells expressed six3 and thus, by molecular identity, appear to represent differentiated cell types of the surrounding apical plate. Hierarchical clustering based on the $48 \mathrm{hpf}$ PrImR data (Figure 6M) supports this distinction: one cluster comprised the flaskshaped sensory-neurosecretory cells and the adjacent serotoninergic cell, which, in addition to the absence of six3 and presence of $o t p, m i R-7$ and $p h c 2$ (see above), expressed carboxypeptidase-E (cpe) and other genes not directly linked to neurosecretion, such as smad2/3. This cluster corresponded to the $o t p+$ cells devoid of $s i x 3$ expression at 24 hpf (see above). Another well-supported cluster 
comprised the crescent cells and the putative mechanosensory cells, which, in addition to six 3 , expressed the microRNA miR-29 (Figure 6H), the ctbl1 and bZIP.TF genes encoding transcription factors of unknown function, and tektin-2, a structural component of microtubules [61]. Note that in our clustering, absence and presence of six3 and foxq2 strictly correlated, indicative of co-regulation [30] (Figure 6M).

The ampullary tuft cells devoid of six3 (and foxq2) exhibited a more separate identity with equal distance to either cluster. With the six + (and foxq2+) mechanosensory and crescent cells, they shared expression of foxJ, which plays a role in the formation of long motile cilia [62], and of three microRNAs of the 'ciliary' group that have previously been found to demarcate locomotory ciliary bands across Bilateria [22]. They shared the expression of the transcription $\operatorname{ch} \times 10$ with the peptidergic cells (Figure 6M).

\section{Discussion}

\section{Evolutionary conservation of apical patterning}

We detected strong similarities in molecular topography around the apical organ of ciliated larvae in protostomes, deuterostomes and cnidarians that we interpret as common heritage. It is highly unlikely that a specific and partially nested pattern involving at least nine transcription factors ( $r x, s i x 3, f o x q 2, f o x j$, otx, otp, irx, $n k x 3, h o x)$ evolves convergently twice. The core of this pattern that is shared between all neuralians appears to be the apical coexpression of two factors, six 3 and foxq2, in sea urchin [26,27], hemichordate [25], annelid (our data), brachiopod [63], sea anemone [28,30] and hydrozoan [64]. In sea urchin and spiralian larvae, these factors demarcate the apical plate and we propose to expand this term to the six $3+$, foxq $2+$ region of all neuralian primary larvae, which should be universally referred to as the apical plate (purple in Figure 7). More peripherally, the apical plate coexpresses $r x$, as demonstrated here for the annelid but as also found in the sea anemone [28] and hemichordate [25] (dark purple in Figure 7). (In sea urchin, $r x$ appears to be expressed in the entire apical plate.) In all neuralians investigated, the specification of the apical plate is sensitive to Wnt signaling, in that pharmacological activation of Wnt signaling abolishes the expression of six3, foxq2 and of other apical markers $([27,28,43,48]$ and our data). The gene regulatory network establishing six 3 and foxq2 expression is only beginning to be elucidated and appears to commonly involve activation of foxq 2 by six3 [30]. In bilaterians, the apical plate also appears to peripherally co-

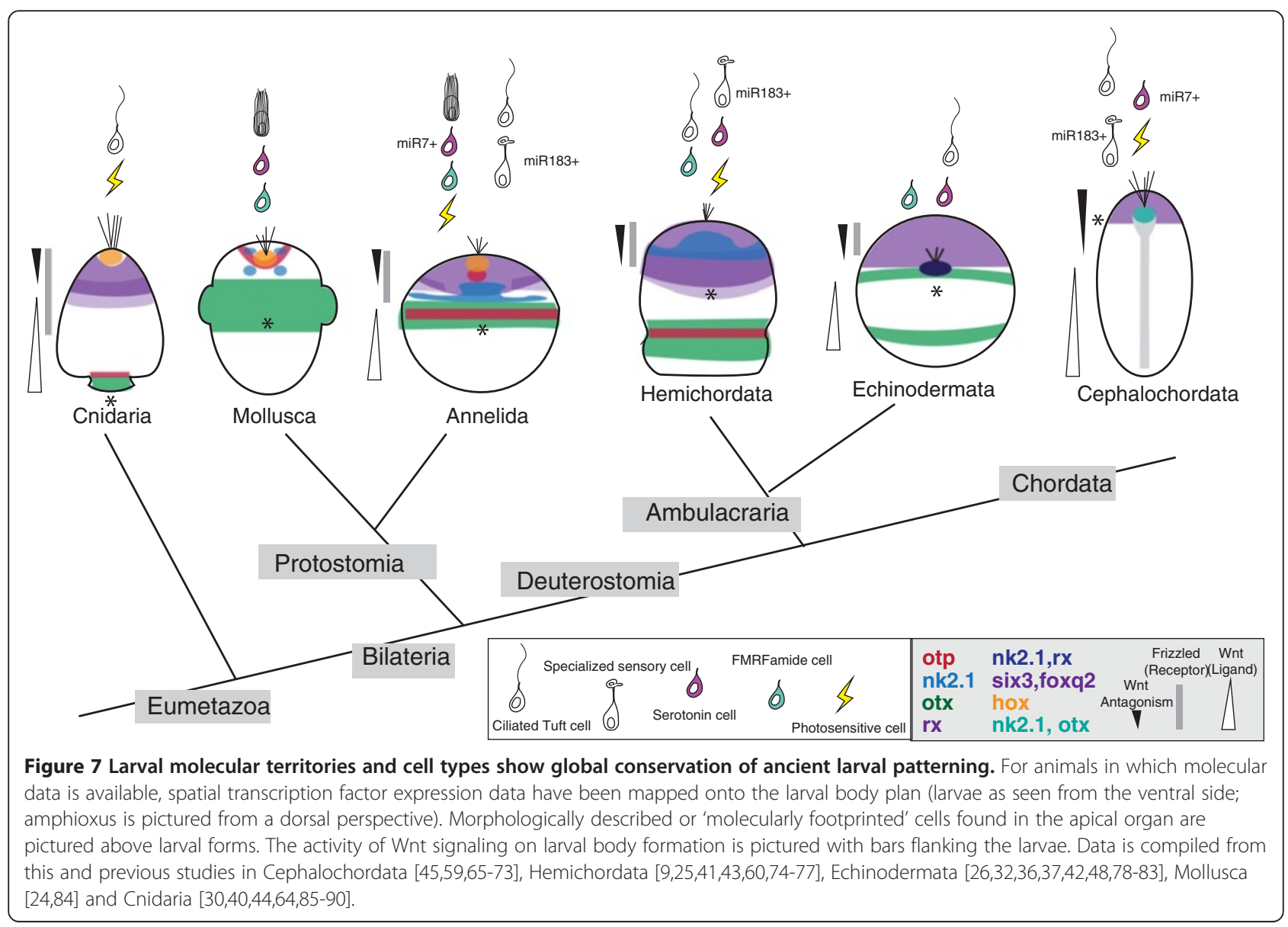


express fezf (in annelid, sea urchin and in Saccoglossus) and ventrally $n k 2.1$ and $h n f 6 /$ onecut (in annelid and in sea urchin; blue in Figure 7).

Notably, although the six $3+, f o x q 2+, r x+, f e z f+, n k 2.1$, onecut + apical plate, as defined here, is a larval character, the same genes are also co-expressed in bilaterian phyla that have lost the primary larva, such as insects and vertebrates, where they specify anterior brain regions $[34,91,92]$. This is consistent with previous observations that, after Platynereis metamorphosis, apical plate markers remain expressed and demarcate the developing cerebral ganglia of the adult nervous system [12]. Therefore, while the stereotypical, partially overlapping co-expression of the above-mentioned genes can be used to topographically 'align' larval body plans, it is not a unique feature of primary ciliated larvae.

\section{A universal molecular definition of the apical organ region}

The apical organ develops in the center of the apical plate. In annelid, sea urchin [37] and sea anemone [28,30], this apical organ region is specifically excluded from the region of six3 expression (in annelid (Figure 3A) and cnidarian (Figure 3C) [30]). Instead, it expresses the transcription factors foxj (in sea anemone [30] and sea urchin [38]), $n k x 3$ (in annelid (Figure 2Q) and sea anemone [28]), irx (in annelid (Figure 2M) and sea anemone [28]) and a hox paralog (in annelid (Figure 2L), mollusk [93] and sea anemone [28]). Note that all of these factors are also expressed elsewhere; for example, in Platynereis, foxj is expressed in other six $3+$ ciliated apical plate cells and, more generally, in ciliary bands; $n k x 3$ is expressed in other apical plate cells (our data) and in segmented mesoderm [94] and hox 1 is expressed in the second larval segment [95] - nevertheless, the recurrent appearance of these factors in the apical organ region across neuralians appears highly significant and we propose that it reflects the evolutionary conservation of apical organ cell types (see below). In addition, apical organ formation appears to similarly depend on local FGF signaling, as shown for sea anemone [14] and as suggested by localization of the $f g$ receptor to the apical plate, in sea urchin [37] and annelid (Figure 2N). Also, the common localization of Tgf $\beta$ signaling inhibitor noggin to the apical organ, as seen in sea anemone [40], sea urchin and in Platynereis, is indicative of conserved signaling events. Together, these transcription factors and signaling molecules provide a highly characteristic molecular signature for the apical organ region (and the cell types therein, see below). Given that the establishment of the six3-'hole' spatially correlates with, and has been functionally linked to, the formation of the apical tuft (see below), we consider this signature a characteristic feature of primary larvae and its apparent evolutionary conservation lends strong support to the notion that these larvae represent an ancient feature of the metazoan life cycle (Figure 1A and see above). It will be interesting to determine to what extent this signature or parts of this signature are present in groups that have lost primary larvae; given the spotted appearance of irx, nkx3, hox and foxj expression in the apical organ region it is likely that any conservation of this signature at adult stages would relate to the persistence of 'apical' cell types throughout the life cycle.

It should be stressed that the hox genes expressed in the apical organ in cnidarian, mollusk and annelid represent different paralogs of the Hox cluster. Anthox1, which demarcates the apical organ in sea anemone, is a 'posterior' hox gene [96]; Lox5, Lox4 and Lox2, which are expressed in different cells of the apical organ of the snail trochophore [93], belong to the middle part of the cluster; and hox 1, that we find expressed in the Platynereis apical organ, is an 'anterior' hox gene. The utilization of different hox paralogs in the apical organ can be explained if one assumes that hox expression in apical organ cells is older than the hox cluster itself and already occurred at the times when a single ur-hox/parahox gene existed [97]. Then, concomitant with subsequent duplication events, the expression of different hox paralogs would have been lost in divergent evolutionary lines. Alternately, the hox paralogs utilized in the apical organ may have been exchanged over time. Additional studies examining the downstream targets of hox expression will be useful in distinguishing between these scenarios.

\section{The apical tuft - ancient nucleation center of apical organs}

If the neuralian ancestors specifically expressed the molecular signature defined above in selected cells of the apical organ region, what cell types did the partaking genes specify and what can we learn about the ancestral composition and function of the neuralian apical organ? Except for Platynereis, cellular resolution molecular fingerprints are not yet available in marine primary larvae, limiting the extent of interphyletic comparison of specific cell types. However, limited molecular evidence is available and adds to a rich body of morphological evidence. The first and most obvious candidates for conserved apical organ cell types are the apical tuft cells that are widespread in Neuralia $[2,11,85,98]$. In Platynereis, the apical tuft cell exhibits a basket-shaped morphology with characteristic intracellular support structures resembling those of ampullary tuft cells in mollusks [11] and stands out with the specific expression of hox1. In the snail Gibbula, expression of Lox4 is confined to 'two cilia-bearing cells of the apical organ' [93]; it is as yet unclear how these relate to the ampullary tuft cells. In sea anemone, injection of anthox 1 morpholino results in planulae lacking the apical tuft [30], corroborating a link between hox expression and 
tuft formation. Given that anthox1 knockdown also abolishes the 'hole' in six 3 expression, one might speculate that the formation of an apical tuft involving restricted hox expression, FGF signaling and apical down-regulation of six3 represents the conserved core of apical organs in Neuralia (see above). This notion would imply, however, a transition from monociliated to multiciliated tuft cells: while the Platynereis apical tuft cell bears multiple long motile cilia, those of some other spiralian and of deuterostome larvae are monociliated [74]; likewise, the cnidarian apical tuft is composed of many cilia that each emerge from single monociliated cells [5]. These long cilia perform a mechanosensory function during sweeping behavior of the benthos $[99,100]$. In the absence of cell type-specific expression data from other neruralian larvae, the evolutionary relationship of the various tuft cells remains speculative; future studies will further clarify their evolutionary relationships within neuralians.

\section{The apical plexus - a conserved sensory-neurosecretory release site for the control of body physiology and metamorphosis}

Besides the apical tuft, the apical plexus directly underneath the apical tuft may belong to the ground pattern of apical organ structures in Neuralia, as it is commonly innervated by flask-shaped, neuropeptidergic sensoryneurosecretory cells from the apical plate or apical organ proper - in mollusks [101,102], sea urchins [78], hemichordates [74] and, likewise, cnidarians [85,103-107]. Among the neuropeptides secreted by these cells into the apical plexus may be two ancient types of short amidated peptides, Wamides and $\mathrm{R}(\mathrm{F} / \mathrm{Y})$ amides, recently proposed to predate neuralians [108]. In cnidarians, RFamidergic sensory neurons from 'anterior' larval regions project into the apical plexus $[85,105,106,109]$. Likewise, RFamidergic cells populate the apical plate and organ in annelids (as shown here and in $[12,110])$, mollusks $[101,102]$, polyclad flatworms [6] and phoronids [111]. Wamides have been implicated in the control of larval settlement in cnidarians $[112,113]$ and, recently, in annelids [15] and are likewise released from the apical plexus. In the late planula larva of the hydrozoan Hydractinia, GLWamide-positive sensory cells that innervate the apical plexus populate a belt around the apical pole [114], which, by position, forms part of the apical plate; MIP, a related Wamide neuropeptide that induces larval settlement in annelids, is secreted into the apical plexus by apical organ cells [15].

In Platynereis, the transcription factor otp demarcates the neuropeptidergic sensory-neurosecretory cells in apical organ (Figure 2G,G',G" and [12]). Since $o t p+$ cells also exist in the apical organ of the snail Patella [84] and are overlapping with six 3 expression in the apical plate of the late Nematostella planula [28], we hypothesize that $o t p+$ sensory-neurosecretory cells projecting to the apical plexus formed part of the apical plate in neuralian ancestors and that subsets of these cells became part of the apical organ in the bilaterian lineage. Another gene demarcating the neuropeptidergic sensory-neurosecretory cells, among other cells, is $n k x 3$. The apparent deep conservation of $n k x 3$ expression in apical organs (see above) suggests an ancient role of $n k x 3$ in the specification of these apical neurons; to find out, a thorough investigation of $n k \times 3+$ cells in other apical organs, for example in the cnidarian planula, will be rewarding.

Besides the neuropeptidergic cells, apical serotoninergic cells represent a third type of neurosecretory cell projecting into the apical plexus. They exist in mollusks [11], echinoderms [78], enteropneusts [98] and other bilaterian phyla [115]. Serotonergic cells are also enriched in apical body regions of the hydrozoan cnidarian Phialidium gregarium, where the release of serotonin has been reported to trigger larval settlement [116]. The molecular identity of serotoninergic apical cells is beginning to be elucidated: the 5HT cell included in our PrImR analysis appears to specifically express $\operatorname{lm} x 1 a b$, a LIM homeodomain factor implicated in serotoninergic specification in nematodes [57], and $n k 2.1$, demarcating serotoninergic cells in sea urchin [36] and, possibly, in the Ptychodera tornaria [75]. Likewise, $f e z f$ has been proposed to correlate with serotoninergic fate in the sea urchin [32]. Further genetic studies on the serotonergic system in various marine larvae will be needed to resolve this issue.

\section{Ambient light detection}

Finally, our study provides strong evidence for photosensitivity being an ancient feature of apical organs. Remarkably, the opsins identified in cells in and around the apical organ in Platynereis (Figure 6K,L), and also in Terebratalia transversa [117] and Nematostella vectensis [86], all fall within the peropsin/ciliary opsin families. These observations indicate that apical organs evolved as multimodal sensory structures, of which photosensitivity formed a key component.

\section{'Minimally indirect development' links apical patterning of larval and adult stages}

The continuous deployment of the apical patterning system at larval and adult stages and the persistence of some apical plate and organ cell types into post-metamorphic stages would suggest that a gradual type of metamorphosis (where the bulk of tissues persist, see below) is more ancient than the 'catastrophic' mode of metamorphosis dubbed maximal indirect development [19]. We refer to such a biphasic life cycle, with gradual and limited metamorphosis in which larval neural structures are incorporated into the adult nervous system, as 'minimally indirect development.' Illustrating this, the Platynereis apical organ tuft cell appears to form a 'nucleation center' 
around which the brain is organized (Figure 6I), and the larval axons pioneer the tracts and nerves of the later nervous system [31,54]. It is possible that the eumetazoan common ancestor showed minimally indirect development with a larval stage resembling the primary ciliary larvae of modern marine bilaterians and cnidarians.

\section{Conclusions}

We have investigated regionalization of the larval episphere, the effects of ectopic activation of Wnt signaling on apical patterning, and the molecular fingerprint of apical cell types in the marine annelid Platynereis dumerilii. Comparing our findings to those in other marine larvae, we present a core set of characteristics common to primary ciliated larvae in bilaterians and cnidarians. All larvae develop an apical plate that we define by a combination of transcription factors most prominently involving six3 and foxq2. Expression of these factors and formation of the apical plate is sensitive to Wnt signaling activity. Finally, a conspicuous apical tuft forms within a central six3-free territory within the apical plate. These similarities are most parsimoniously explained by common origin. We accordingly propose that the last common ancestor of bilaterians and cnidarians developed via primary larvae that possessed an apical tuft as part of a simple apical organ. A basal plexus may have formed directly underneath the apical organ, which was innervated by sensory-neurosecretory apical plate cells. We hypothesize that an ancient function of the apical organ was the control of metamorphosis and opsin-based ambient light perception. Various types of additional apical plate cells would then have subsequently been recruited to form part of the apical organ in the divergent bilaterian lineages. Our findings support an ancient and common origin of primary ciliated larvae.

\section{Methods}

Isolation of Platynereis genes and sequence analysis

Partial sequences for pdu-fgfr, pdu-foxq2, pdu-irx, pdufoxJ1, pdu-hnf6, pdu-wnt4, pdu-frizzled5/8, pdu-sfrp1/5 and pdu-peropsin were assembled from Platynereis transcriptome and genome resources, amplified with specific primers, and extended with rapid amplification of cDNA ends PCR. Pdu-CTBL1, Pdu-bZIP-TF, Pdutektin-2, Pdu-spondin, Pdu-gbrl, Pdu-cpe, Pdu-smad2/3 and Pdu-klf2/4 were characterized during a whole mount in situ hybridization screen from expressed sequence tag clones (RT and DA, unpublished). The GenBank accession numbers for peropsin, foxj, fezf, onecut, fgfR, noggin, foxq2, frizzled4, frizzled5/8, frizzled9/10 and sfrp1/5 are [GenBank:KF844232] to [GenBank:KF844242] respectively. Accession numbers for ctbl1, spondin, gbr1, cpe, ces2 and klf are [GenBank:KF835846] to [GenBank: KF835851] respectively.

\section{In situ hybridizations and immunostainings}

For in situ hybridizations at early stages, Platynereis larvae were fixed in 4\% PFA, $0.1 \mathrm{M}$ MOPS, 2 mM EGTA, $1 \mu \mathrm{M} \mathrm{MgSO} 4$ and $0.1 \%$ Tween-20, for 4 to 6 hours at $4^{\circ} \mathrm{C}$, then rinsed in PTW and ice cold methanol, followed by storage in methanol at -20C.

In situ hybridization for early Platynereis larvae were performed as in $[118,119]$ with the following modifications. Embryos were digested with $0.1 \mathrm{mg} / \mathrm{mL}$ proteinaseK for 30 seconds (Merck 7066304, Darmstadt, Germany). Following hybridization, $0.5 \times \mathrm{SSC}$ washes were replaced by $0.15 \times$ SSC washes for 15 rather than 30 minutes. In situ hybridizations were performed for $48 \mathrm{hpf}$ Platynereis and microRNA as previously published $[22,118]$. The axonal scaffold was counterstained with an antibody against tyrosinated or acetylated-tubulin (1:500, Sigma T9028 and T6793). Immunostainings were performed as described [12] with the following primary antibodies: mouse anti-acetylated tubulin (1:500, Sigma T6793), rabbit antiserotonin (1:500, ImmunoStar 20080) and rabbit antiFMRF (1:200, Phoenix Pharmaceuticals, H-047-29).

For the staining of mitotic cells, Platynereis larvae were incubated in $10 \mu \mathrm{M}$ EdU (Click-iT EdU Imaging Kit, Invitrogen, C10340) from 22 to 24 hpf; EdU incorporation was detected after the incubation with secondary antibodies, following manufacturer instructions.

\section{Alsterpaullone and azakenpaullone treatments}

Platynereis larvae were incubated from 12 to $24 \mathrm{hpf}$ in five different concentrations of azakenpaullone (0.1 to $10 \mu \mathrm{M}$ ) in $0.5 \%$ dimethyl sulfoxide (DMSO) in filtered seawater. The number of embryos displaying wild-type, reduced or expanded expression patterns for episphere molecular markers were assessed from two different biological replicates (numbers of embryos displaying each pattern are indicated in Figure 5). As most genes assayed were significantly affected at 1 and $5 \mu \mathrm{M}$ concentrations, we conducted washout experiments at these concentrations. Larvae were exposed to azakenpaullone from 12 to $24 \mathrm{hpf}$ and subsequently washed out of the pharmacological treatment into $0.5 \%$ DMSO and incubated in $0.5 \%$ DMSO from 24 to $30 \mathrm{hpf}$. Controls were maintained in $0.5 \%$ DMSO from 12 to $24 \mathrm{hpf}$ and washed into a new $0.5 \%$ DMSO treatment from 24 to $30 \mathrm{hpf}$. Embryos were examined and assessed in relation to control-treated embryos. Effects of alsterpaullone were also assayed, compared to those of azakenpaullone, and found to be similar to azakenpaullone treatments (Additional file 1: Figure S2).

\section{Microscopy and image processing}

We used reflection microscopy [120] to acquire confocal images of in situ hybridization stainings. Fluorescent signals in Figure 2Q', Figure $4 \mathrm{C}$ and Figure $4 C^{\prime}$ were 
obtained using the fluorescent signal emitted from NBT/ BCIP precipitate, an alternate method to reflection microscopy. Confocal stacks were taken on a Leica TCS SPE with a $40 \times$ oil immersion objective. Images were processed with ImageJ, utilizing either brightest point or average intensity settings to generate projections. Subsequently, images were cropped and processed in Photoshop, Adobe, San Jose, California, USA; brightness and contrast were adjusted equally across the entire image.

For PrImR, average expression patterns at $48 \mathrm{hpf}$ were obtained after image registration of in situ confocal scans on a common reference axonal scaffold, as described in [47].

\section{Molecular fingerprint analysis}

Morphologically distinct apical organ cell types were identified by analyzing immunostained larvae at early stages (24 and $30 \mathrm{hpf}$ ). These cells were then located in $48 \mathrm{hpf}$ larvae for the gene expression analysis with PrImR. The co-localization between two average gene expression patterns was inspected and visualized using the 'Colocalization highlighter' plugin in ImageJ.

Whenever a PrImR average expression pattern was not available for the gene and/or the stage of interest, specimens stained with the gene of interest and tyrosinated tubulin were inspected under fluorescence microscopy.

Hierarchical clustering of molecular fingerprints was carried in $\mathrm{R}$ (the $\mathrm{R}$ Project for Statistical Computing) from the dataset in Additional file 1: Figure S5, using Pearson correlation and average linkage.

\section{Phylogenetic analyses for gene orthologies}

Platynereis dumerilii gene coding sequences used in this study were isolated as described above. Sequence data from the lophotrochozoans Lottia gigantea and Capitella teleta and the cnidarian Nematostella vectensis were identified on their respective JGI genome portal webservers. Additional sequences used in the analyses were downloaded from Treefam [121]. Multiple alignments of predicted proteins were generated with MUSCLE using the default settings [122] and were subsequently inspected and corrected by eye. Full alignments were trimmed using G-blocks [123] and were run through ProtTest using the default settings to determine the optimum evolutionary model for phylogenetic analyses [124]. Neighbor joining trees were constructed using MEGA [125] and maximum likelihood analyses were conducted using PhyML [126] with the amino acid substitution models specified from ProtTest. Phylogenetic trees are available in Additional file 2.

\section{Additional files}

Additional file 1: Figure S1. miR183 expression in a 48 hpf larva. Figure S2. Alsterpaullone treated embryos. Figure S3. Azakenpaullone treated embryos following washout. Figure S4. Percentages of affected embryos in azakenpaullone treatments. Figure S5. PrlmR analysis of the expression of transcription factors, miRNAs and differentiation markers in defined apical organ cell types.

Additional file 2: Phylogenetic analysis for the assignment of gene orthology.

\section{Abbreviations}

DMSO: dimethyl sulfoxide; Fgf: fibroblast growth factor; hpf: Hours postfertilization; PCR: polymerase chain reaction; PrImR: profiling by image registration; Tgf: transforming growth factor.

\section{Competing interests}

The authors declare that they have no competing interests.

\section{Authors' contributions}

HM and DA designed the study. HM collected in situ expression data and performed alsterpaullone and azakenpaullone treatments. MAT generated and analyzed molecular fingerprint data, performed clustering analysis and characterized cell morphologies. RT cloned multiple genes and generated averaged expression data for Profiling by Image Registration. PRS cloned the fgfR gene. AL contributed to TrpV cloning and expression analysis. TL generated phylogenetic analyses for gene orthologies. HM, MAT and DA wrote the paper. All authors read and approved the final manuscript.

\section{Acknowledgements}

We thank all of the members of the Arendt group for useful discussion and F. Christodoulou and G. Jekely for contributing averaged expression patterns to the PrlmR database. We also thank Antje Fischer for sharing preliminary expression data for $n k \times 3.1$ in the Platynereis brain. We are also very grateful to Dr. Claus Nielsen for contributing his original drawings that have greatly improved the quality of Figure 1 and also thank him and two anonymous reviewers for their improvement of the manuscript. The work was supported by: the European Molecular Biology Laboratory (RT, TL, DA); the EMBL International PhD Programme (PRS, AL); and the EMBL Interdisciplinary Postdoc Programme under Marie Curie Actions COFUND (HM) and by the European Union's Seventh Framework Programme project: ERCEA-AdG-2011294810_'BrainEvoDevo'.

\section{Author details}

${ }^{1}$ European Molecular Biology Laboratory, Development Biology Unit, EMBL Heidelberg, Meyerhofstraße 1, 69117 Heidelberg, Germany. ${ }^{2}$ Present address: Howard Hughes Medical Institute, Stanford University, Stanford, CA 94305, USA. ${ }^{3}$ Present address: Department for Molecular Evolution and Development, Centre for Organismal Systems Biology, University of Vienna, Althanstraße 14, A-1090 Vienna, Austria. ${ }^{4}$ Present address: Institute for Biological and Medical Imaging, Helmholtz Zentrum München, Ingolstädter Landstr. 1, 85764 München, Germany. ${ }^{5}$ European Molecular Biology Laboratory, Structural and Computational Biology Unit, Meyerhofstraße 1, 69117 Heidelberg, Germany.

Received: 4 November 2013 Accepted: 24 January 2014 Published: 29 January 2014

\section{References}

1. Young CM, Sewell MA: Atlas of Marine Invertebrate Larvae. Academic Press: Waltham, MA, USA; 2006

2. Nielsen C: Trochophora larvae: cell-lineages, ciliary bands, and body regions. 1. Annelida and mollusca. J Exp Zool (Mol Dev Evol) 2004, 302B:35-68.

3. Nielsen C: Trochophora larvae: cell-lineages, ciliary bands and body regions. 2. Other groups and general discussion. J Exp Zool B Mol Dev Evol 2005, 304:401-447

4. Jekely G: Origin and early evolution of neural circuits for the control of ciliary locomotion. Proc Biol Sci 2011, 278:914-922.

5. Chia FS, Koss R: Fine-structural studies of the nervous-system and the apical organ in the planula larva of the sea-anemone Anthopleura elegantissima. J Morph 1979, 160:275-298. 
6. Rawlinson KA: Embryonic and post-embryonic development of the polyclad flatworm Maritigrella crozieri; implications for the evolution of spiralian life history traits. Front Zool 2010, 7:12.

7. Hindinger S, Schwaha T, Wanninger A: Immunocytochemical studies reveal novel neural structures in nemertean pilidium larvae and provide evidence for incorporation of larval components into the juvenile nervous system. Front Zool 2013, 10:31.

8. Byrne $M$, Nakajima Y, Chee FC, Burke RD: Apical organs in echinoderm larvae: insights into larval evolution in the Ambulacraria. Evol Dev 2007, 9:432-445.

9. Miyamoto N, Nakajima Y, Wada H, Saito Y: Development of the nervous system in the acorn worm Balanoglossus simodensis: insights into nervous system evolution. Evol Dev 2010, 12:416-424.

10. Nielsen C: Six major steps in animal evolution: are we derived sponge larvae? Evol Dev 2008, 10:241-257.

11. Kempf SC, Page LR, Pires A: Development of serotonin-like immunoreactivity in the embryos and larvae of nudibranch mollusks with emphasis on the structure and possible function of the apical sensory organ. $J$ Comp Neurol 1997, 386:507-528.

12. Tessmar-Raible K, Raible F, Christodoulou F, Guy K, Rembold M, Hausen H, Arendt D: Conserved sensory-neurosecretory cell types in annelid and fish forebrain: insights into hypothalamus evolution. Cell 2007, 129:1389-1400.

13. Hadfield MG, Meleshkevitch EA, Boudko DY: The apical sensory organ of a gastropod veliger is a receptor for settlement cues. Biol Bull 2000, 198:67-76.

14. Rentzsch F, Fritzenwanker JH, Scholz CB, Technau U: FGF signalling controls formation of the apical sensory organ in the cnidarian Nematostella vectensis. Development 2008, 135:1761-1769.

15. Conzelmann M, Williams EA, Tunaru S, Randel N, Shahidi R, Asadulina A, Berger J, Offermanns S, Jekely G: Conserved MIP receptor-ligand pair regulates Platynereis larval settlement. Proc Natl Acad Sci USA 2013, 14:8224-8229

16. Nielsen C: Animal Evolution. Interrelationships of the Living Phyla. 3rd edition. Oxford: Oxford University Press; 2012.

17. Jägersten G: Evolution of the Metazoan Life Cycle: A Comprehensive Theory London, New York: Academic Press; 1972.

18. Raff RA: Origins of the other metazoan body plans: the evolution of larval forms. Philos Trans R Soc Lond B Biol Sci 2008, 363:1473-1479.

19. Peterson KJ, Cameron RA, Davidson EH: Set-aside cells in maximal indirect development: evolutionary and developmental significance. Bioessays 1997, 19:623-631.

20. Wolpert L: From egg to adult to larva. Evol Dev 1999, 1:3-4.

21. Arendt $D$, Technau U, Wittbrodt J: Evolution of the bilaterian larval foregut. Nature 2001, 409:81-85.

22. Christodoulou F, Raible F, Tomer R, Simakov O, Trachana K, Klaus S, Snyman H, Hannon GJ, Bork P, Arendt D: Ancient animal microRNAs and the evolution of tissue identity. Nature 2010, 463:1084-1088.

23. Harada Y, Okai N, Taguchi S, Tagawa K, Humphreys T, Satoh N: Developmental expression of the hemichordate otx ortholog. Mech Dev 2000, 91:337-339.

24. Dunn EF, Moy VN, Angerer LM, Angerer RC, Morris RL, Peterson KJ: Molecular paleoecology: using gene regulatory analysis to address the origins of complex life cycles in the late Precambrian. Evol Dev 2007, 9:10-24.

25. Lowe CJ, Wu M, Salic A, Evans L, Lander E, Stange-Thomann N, Gruber CE, Gerhart J, Kirschner M: Anteroposterior patterning in hemichordates and the origins of the chordate nervous system. Cell 2003, 113:853-865.

26. Yankura KA, Martik ML, Jennings CK, Hinman VF: Uncoupling of complex regulatory patterning during evolution of larval development in echinoderms. BMC Biol 2010, 8:143.

27. Wei Z, Yaguchi J, Yaguchi S, Angerer RC, Angerer LM: The sea urchin animal pole domain is a six3-dependent neurogenic patterning center. Development 2009, 136:1179-1189.

28. Marlow H, Matus DQ, Martindale MQ: Ectopic activation of the canonical Wnt signaling pathway affects ectodermal patterning along the primary axis during larval development in the anthozoan Nematostella vectensis. Dev Biol 2013, 380:324-334.

29. Range RC, Angerer RC, Angerer LM: Integration of canonical and noncanonical Wnt signaling pathways patterns the neuroectoderm along the anterior-posterior axis of sea urchin embryos. PLOS Biol 2013, 11:e1001467.
30. Sinigaglia C, Busengdal $H$, Leclere L, Technau U, Rentzsch F: The bilaterian head patterning gene six $3 / 6$ controls aboral domain development in a cnidarian. PLOS Biol 2013, 11:e1001488.

31. Fischer $\mathrm{AH}$, Henrich $\mathrm{T}$, Arendt D: The normal development of Platynereis dumerilii (Nereididae, Annelida). Front Zool 2010, 7:31.

32. Yaguchi S, Yaguchi J, Wei Z, Jin Y, Angerer LM, Inaba K: Fez function is required to maintain the size of the animal plate in the sea urchin embryo. Development 2011, 138:4233-4243.

33. Scholpp S, Lumsden A: Building a bridal chamber: development of the thalamus. Trends Neurosci 2010, 33:373-380.

34. Steinmetz PR, Urbach R, Posnien N, Eriksson J, Kostyuchenko RP, Brena C, Guy K, Akam M, Bucher G, Arendt D: Six3 demarcates the anterior-most developing brain region in bilaterian animals. Evodevo 2010, 1:14.

35. Arendt D, Tessmar-Raible K, Snyman H, Dorresteijn AW, Wittbrodt J: Ciliary photoreceptors with a vertebrate-type opsin in an invertebrate brain. Science 2004, 306:869-871.

36. Takacs CM, Amore G, Oliveri P, Poustka AJ, Wang D, Burke RD, Peterson KJ: Expression of an NK2 homeodomain gene in the apical ectoderm defines a new territory in the early sea urchin embryo. Dev Biol 2004, 269:152-164.

37. Poustka AJ, Kuhn A, Groth D, Weise V, Yaguchi S, Burke RD, Herwig R, Lehrach $\mathrm{H}$, Panopoulou G: A global view of gene expression in lithium and zinc treated sea urchin embryos: new components of gene regulatory networks. Genome Biol 2007, 8:R85.

38. Tu Q, Brown CT, Davidson EH, Oliveri P: Sea urchin forkhead gene family: phylogeny and embryonic expression. Dev Biol 2006, 300:49-62.

39. Duboc V, Rottinger E, Besnardeau L, Lepage T: Nodal and BMP2/4 signaling organizes the oral-aboral axis of the sea urchin embryo. Dev Cell 2004, 6:397-410.

40. Matus DQ, Pang K, Marlow H, Dunn CW, Thomsen GH, Martindale MQ: Molecular evidence for deep evolutionary roots of bilaterality in animal development. Proc Natl Acad Sci U S A 2006, 103:11195-11200.

41. Rottinger $E$, Martindale $M Q$ : Ventralization of an indirect developing hemichordate by $\mathrm{NiCl}(2)$ suggests a conserved mechanism of dorso-ventral (D/V) patterning in Ambulacraria (hemichordates and echinoderms). Dev Biol 2011, 354:173-190.

42. Illies MR, Peeler MT, Dechtiaruk A, Ettensohn CA: Cloning and developmental expression of a novel, secreted frizzled-related protein from the sea urchin, Strongylocentrotus purpuratus. Mech Dev 2002, 113:61-64.

43. Darras S, Gerhart J, Terasaki M, Kirschner M, Lowe CJ: $\beta$-catenin specifies the endomesoderm and defines the posterior organizer of the hemichordate Saccoglossus kowalevskii. Development 2011, 138:959-970.

44. Kusserow A, Pang K, Sturm C, Hrouda M, Lentfer J, Schmidt HA, Technau U, von Haeseler A, Hobmayer B, Martindale MQ, Holstein TW: Unexpected complexity of the Wnt gene family in a sea anemone. Nature 2005, 433:156-160.

45. Schubert M, Holland LZ, Holland ND: Characterization of two amphioxus Wnt genes (AmphiWnt4 and AmphiWnt7b) with early expression in the developing central nervous system. Dev Dyn 2000, 217:205-215.

46. Janssen R, Le Gouar M, Pechmann M, Poulin F, Bolognesi R, Schwager EE, Hopfen C, Colbourne JK, Budd GE, Brown SJ, Prpic NM, Kosiol C, Vervoort M, Damen WG, Balavoine G, McGregor AP: Conservation, loss, and redeployment of Wnt ligands in protostomes: implications for understanding the evolution of segment formation. BMC Evol Biol 2010, $10: 374$.

47. Tomer R, Denes A, Tessmar-Raible K, Arendt D: Cellular resolution expression profiling reveals common origin of annelid mushroom bodies and vertebrate pallium. Cell 2010, 142:800-809.

48. Yaguchi S, Yaguchi J, Angerer RC, Angerer LM: A Wnt-FoxQ2-nodal pathway links primary and secondary axis specification in sea urchin embryos. Dev Cell 2008, 14:97-107.

49. Leost M, Schultz C, Link A, Wu YZ, Biernat J, Mandelkow EM, Bibb JA, Snyder GL, Greengard P, Zaharevitz DW, Gussio R, Senderowicz AM, Sausville EA, Kunick C, Meijer L: Paullones are potent inhibitors of glycogen synthase kinase-3beta and cyclin-dependent kinase 5/p25. Eur J Biochem 2000, 267:5983-5994.

50. Schneider SQ, Bowerman B: beta-Catenin asymmetries after all animal/ vegetal- oriented cell divisions in Platynereis dumerilii embryos mediate binary cell-fate specification. Dev Cell 2007, 13:73-86.

51. Arendt D, Tessmar K, de Campos-Baptista MI, Dorresteijn A, Wittbrodt J: Development of pigment-cup eyes in the polychaete Platynereis 
dumerilii and evolutionary conservation of larval eyes in Bilateria. Development 2002, 129:1143-1154.

52. Byrne M, Sewell MA, Selvakumaraswamy P, Prowse TA: The larval apical organ in the holothuroid Chiridota gigas (Apodida): inferences on evolution of the Ambulacrarian larval nervous system. Biol Bull 2006, 211:95-100.

53. Lacalli TC, Kelly SJ: Anterior neural centres in echinoderm bipinnaria and auricularia larvae: cell types and organization. Acta Zoologica (Stockholm) 2002, 83:99-110

54. Lacalli TC: Structure and development of the apical organ in trochophores of Spirobranchus polycerus, Phyllodoce maculata, and Phyllodoce mucosa (Polychaeta). Proc R Soc Lond B 1981,

212:381-402.

55. Conzelmann M, Offenburger SL, Asadulina A, Keller T, Munch TA, Jekely G: Neuropeptides regulate swimming depth of Platynereis larvae. Proc Natl Acad Sci USA 2011, 108:E1174-E1183.

56. Koyanagi M, Terakita A, Kubokawa K, Shichida Y: Amphioxus homologs of Go-coupled rhodopsin and peropsin having 11-cis- and all-trans-retinals as their chromophores. FEBS Lett 2002, 531:525-528.

57. Flames $\mathrm{N}$, Hobert O: Transcriptional control of the terminal fate of monoaminergic neurons. Annu Rev Neurosci 2011, 34:153-184.

58. Kim J, Chung YD, Park DY, Choi S, Shin DW, Soh H, Lee HW, Son W, Yim J, Park CS, Kernan MJ, Kim C: A TRPV family ion channel required for hearing in Drosophila. Nature 2003, 424:81-84.

59. Candiani S, Moronti L, De Pietri Tonelli D, Garbarino G, Pestarino M: A study of neural-related microRNAs in the developing amphioxus. Evodevo 2011, 2:15.

60. Pierce ML, Weston MD, Fritzsch B, Gabel HW, Ruvkun G, Soukup GA: MicroRNA-183 family conservation and ciliated neurosensory organ expression. Evol Dev 2008, 10:106-113.

61. Amos LA: The tektin family of microtubule-stabilizing proteins. Genome Biol 2008, 9:229.

62. Yu X, Ng CP, Habacher H, Roy S: Foxj1 transcription factors are master regulators of the motile ciliogenic program. Nat Genet 2008, 40:1445-1453.

63. Santagata S, Resh C, Hejnol A, Martindale MQ, Passamaneck YJ: Development of the larval anterior neurogenic domains of Terebratalia transversa (Brachiopoda) provides insights into the diversification of larval apical organs and the spiralian nervous system. Evodevo 2012, 3:3.

64. Chevalier S, Martin A, Leclere L, Amiel A, Houliston E: Polarised expression of FoxB and FoxQ2 genes during development of the hydrozoan Clytia hemisphaerica. Dev Genes Evol 2006, 216:709-720.

65. Ogasawara M: Overlapping expression of amphioxus homologs of the thyroid transcription factor-1 gene and thyroid peroxidase gene in the endostyle: insight into evolution of the thyroid gland. Dev Genes Evol 2000, 210:231-242.

66. Yu JK, Mazet F, Chen YT, Huang SW, Jung KC, Shimeld SM: The Fox genes of Branchiostoma floridae. Dev Genes Evol 2008, 218:629-638.

67. Onai T, Lin HC, Schubert M, Koop D, Osborne PW, Alvarez S, Alvarez R, Holland ND, Holland LZ: Retinoic acid and Wnt/beta-catenin have complementary roles in anterior/posterior patterning embryos of the basal chordate amphioxus. Dev Biol 2009, 332:223-233.

68. Williams NA, Holland PWH: Old head on young shoulders. Nature 1996, 383:490.

69. Zhang Y, Mao B: Embryonic expression and evolutionary analysis of the amphioxus Dickkopf and Kremen family genes. J Genet Genomics 2010, 37:637-645

70. Kozmik Z, Holland ND, Kreslova J, Oliveri D, Schubert M, Jonasova K, Holland LZ, Pestarino M, Benes V, Candiani S: Pax-Six-Eya-Dach network during amphioxus development: conservation in vitro but context specificity in vivo. Dev Biol 2007, 306:143-159.

71. Holland ND, Holland LZ: Serotonin-containing cells in the nervous system and other tissues during ontogeny of a lancelet, Branchiostoma floridae. Acta Zool (Stockh) 1993, 74:195-204.

72. Lacalli TC: Frontal eye circuitry, rostral sensory pathways and brain organization in amphioxus larvae: evidence from 3D reconstructions. Philos T Roy Soc London B Biol Sci 1996, 351:243-263.

73. Lacalli TC, Kelly SJ: The infundibular balance organ in amphioxus larvae and related aspects of cerebral vesicle organization. Acta Zoologica (Stockholm) 2000, 81:43-47.
74. Nezlin LP, Yushin W: Structure of the nervous system in the tornaria larva of Balanoglossus proterogonius (Hemichordata: Enteropneusta) and its phylogenetic implications. Zoomorphology 2004, 123:1-13.

75. Takacs CM, Moy VN, Peterson KJ: Testing putative hemichordate homologues of the chordate dorsal nervous system and endostyle: expression of NK2.1 (TTF-1) in the acorn worm Ptychodera flava (Hemichordata, Ptychoderidae). Evol Dev 2002, 4:405-417.

76. Tagawa K, Satoh N, Humphreys T: Molecular studies of hemichordate development: a key to understanding the evolution of bilateral animals and chordates. Evol Dev 2001, 3:443-454.

77. Nakajima Y, Humphreys T, Kaneko H, Tagawa K: Development and neural organization of the tornaria larva of the Hawaiian hemichordate, Ptychodera flava. Zoolog Sci 2004, 21:69-78.

78. Beer A-J, Moss C, Thorndyke M: Development of serotonin-like and SALMFamide-like immunoreactivity in the nervous system of the sea urchin Psammechinus miliaris. Biol Bull 2001, 200:268-280.

79. Di Bernardo M, Castagnetti S, Bellomonte D, Oliveri P, Melfi R, Palla F Spinelli G: Spatially restricted expression of PIOtp, a Paracentrotus lividus orthopedia-related homeobox gene, is correlated with oral ectodermal patterning and skeletal morphogenesis in late-cleavage sea urchin embryos. Development 1999, 126:2171-2179.

80. Burke RD, Angerer LM, Elphick MR, Humphrey GW, Yaguchi S, Kiyama T, Liang S, Mu X, Agca C, Klein WH, Brandhorst BP, Rowe M, Wilson K, Churcher AM, Taylor JS, Chen N, Murray G, Wang D, Mellott D, Olinski R, Hallböök F, Thorndyke MC: A genomic view of the sea urchin nervous system. Dev Biol 2006, 300:434-460

81. Howard-Ashby M, Materna SC, Brown CT, Chen L, Cameron RA, Davidson EH: Identification and characterization of homeobox transcription factor genes in Strongylocentrotus purpuratus, and their expression in embryonic development. Dev Biol 2006, 300:74-89.

82. Mitsunaga-Nakatsubo K, Akasaka K, Sakamoto N, Takata K, Matsumura Y, Kitajima T, Kusunoki S, Shimada H: Differential expression of sea urchin Otx isoform (hpOtxE and HpOtxL) mRNAs during early development. Int J Dev Biol 1998, 42:645-651.

83. Croce J, Duloquin L, Lhomond G, McClay DR, Gache C: Frizzled5/8 is required in secondary mesenchyme cells to initiate archenteron invagination during sea urchin development. Development 2006, 133:547-557.

84. Nederbragt AJ, te Welscher $P$, van den Driesche $S$, van Loon AE, Dictus WJ: Novel and conserved roles for orthodenticle/otx and orthopedia/otp orthologs in the gastropod mollusc Patella vulgata. Dev Genes Evol 2002, 212:330-337.

85. Marlow HQ, Srivastava M, Matus DQ, Rokhsar D, Martindale MQ: Anatomy and development of the nervous system of Nematostella vectensis, an anthozoan cnidarian. Dev Neurobiol 2009, 69:235-254.

86. Marlow H: Cell type diversity and developmental mechanisms in larval and adult anthozoan cnidarians. PhD thesis. University of Hawaii; 2011.

87. Mazza ME, Pang K, Reitzel AM, Martindale MQ, Finnerty JR: A conserved cluster of three PRD-class homeobox genes (homeobrain, $r x$ and orthopedia) in the Cnidaria and Protostomia. Evodevo 2010, 1:3.

88. Mazza ME, Pang K, Martindale MQ, Finnerty JR: Genomic organization, gene structure, and developmental expression of three clustered otx genes in the sea anemone Nematostella vectensis. J Exp Zool B Mol Dev Evol 2007, 308:494-506.

89. Lee PN, Pang K, Matus DQ, Martindale MQ: A WNT of things to come: evolution of Wnt signaling and polarity in cnidarians. Semin Cell Dev Biol 2006, 17:157-167.

90. Kumburegama S, Wijesena N, Xu R, Wikramanayake AH: Strabismusmediated primary archenteron invagination is uncoupled from Wnt/ beta-catenin-dependent endoderm cell fate specification in Nematostella vectensis (Anthozoa, Cnidaria): implications for the evolution of gastrulation. Evodevo 2011, 2:2.

91. Posnien N, Koniszewski N, Hein HJ, Bucher G: Candidate gene screen in the red flour beetle Tribolium reveals six3 as ancient regulator of anterior median head and central complex development. PLoS Genet 2011, 7:e1002416.

92. Loosli F, Köster RW, Carl M, Krone A, Wittbrodt J: Six3, a medaka homologue of the Drosophila homeobox gene sine oculis is expressed in the anterior embryonic shield and the developing eye. Mech Dev 1998, 74:159-164. 
93. Samadi L, Steiner G: Expression of Hox genes during the larval development of the snail, Gibbula varia (L.)-further evidence of non-colinearity in molluscs. Dev Genes Evol 2010, 220:161-172.

94. Saudemont A, Dray N, Hudry B, Le Gouar M, Vervoort M, Balavoine G: Complementary striped expression patterns of NK homeobox genes during segment formation in the annelid Platynereis. Dev Biol 2008, 317:430-443.

95. Steinmetz PR, Kostyuchenko RP, Fischer A, Arendt D: The segmental pattern of otx, gbx, and Hox genes in the annelid Platynereis dumerilii. Evol Dev 2011, 13:72-79.

96. Ryan JF, Mazza ME, Pang K, Matus DQ, Baxevanis AD, Martindale MQ, Finnerty JR: Pre-bilaterian origins of the Hox cluster and the Hox code: evidence from the sea anemone, Nematostella vectensis. PLoS One 2007, 2:e153.

97. Mendivil Ramos O, Barker D, Ferrier DE: Ghost loci imply Hox and ParaHox existence in the last common ancestor of animals. Curr Biol 2012, 22:1951-1956.

98. Nielsen C, Hay-Schmidt A: Development of the enteropneust Ptychodera flava: ciliary bands and nervous system. J Morphol 2007, 268:551-570.

99. Tranter $\mathrm{P}$, Nicholson D, Kinchington DA: A description of spawning and post-gastrula development of the cool temperate coral, Caryophyllia smithi. J Mar Biol Assoc U K 1982, 62:845-854.

100. Schwarz J, Weis $V$, Potts D: Feeding behavior and acquisition of zooxanthellae by planula larvae of the sea anemone Anthopleura elegantissima. Mar Biol 2002, 140:471-478.

101. Voronezhskaya EE, Tyurin SA, Nezlin LP: Neuronal development in larval chiton Ischnochiton hakodadensis (Mollusca: Polyplacophora). J Comp Neurol 2002, 444:25-38.

102. Croll RP: Development of embryonic and larval cells containing serotonin, catecholamines, and FMRFamide-related peptides in the gastropod mollusc Phestilla sibogae. Biol Bull 2006, 211:232-247.

103. Grimmelikhuijzen CJ, Graff D, McFarlane ID: Neurones and neuropeptides in coelenterates. Arch Histol Cytol 1989, 52:265-278.

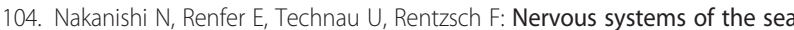
anemone Nematostella vectensis are generated by ectoderm and endoderm and shaped by distinct mechanisms. Development 2012, 139:347-357.

105. Nakanishi N, Yuan D, Jacobs DK, Hartenstein V: Early development, pattern, and reorganization of the planula nervous system in Aurelia (Cnidaria, Scyphozoa). Dev Genes Evol 2008, 218:511-524.

106. Martin VJ: Characterization of a RFamide-positive subset of ganglionic cells in the hydrozoan planular nerve net. Cell Tissue Res 1992, 269:431-438.

107. Leitz T, Lay M: Metamorphosin A is a neuropeptide. Roux's Arch Dev Biol 1995, 204:276-279.

108. Jekely $\mathrm{G}$ : Global view of the evolution and diversity of metazoan neuropeptide signaling. Proc Natl Acad Sci U S A 2013, 110:8702-8707.

109. Jacobs DK, Nakanishi N, Yuan D, Camara A, Nichols SA, Hartenstein V: Evolution of sensory structures in basal metazoa. Integr Comp Biol 2007, 47:712-723.

110. Voronezhskaya EE, Tsitrin EB, Nezlin LP: Neuronal development in larval polychaete Phyllodoce maculata (Phyllodocidae). J Comp Neurol 2003, 455:299-309.

111. Temereva $E$, Wanninger A: Development of the nervous system in Phoronopsis harmeri (Lophotrochozoa, Phoronida) reveals both deuterostome- and trochozoan-like features. BMC Evol Biol 2012, 12:121.

112. Takahashi T, Hatta M: The importance of GLWamide neuropeptides in cnidarian development and physiology. J Amino Acids 2011, 2011:424501.

113. Iwao K, Fujisawa T, Hatta M: A cnidarian neuropeptide of the GLWamide family induces metamorphosis of reef-building corals in the genus Acropora. Coral Reefs 2002, 21:127-129.

114. Schmich J, Trepel S, Leitz T: The role of GLWamides in metamorphosis of Hydractinia echinata. Dev Genes Evol 1998, 208:267-273.

115. Hay-Schmidt $A$ : The evolution of the serotonergic nervous system. Proc $R$ Soc Lond B 2000, 267:1071-1079.

116. McCauley DW: Serotonin plays an early role in the metamorphosis of the hydrozoan Phialidium gregarium. Dev Biol 1997, 190:229-240.

117. Passamaneck YJ, Furchheim N, Hejnol A, Martindale MQ, Luter C: Ciliary photoreceptors in the cerebral eyes of a protostome larva. EvoDevo 2011, 2:6.

118. Denes AS, Jekely G, Steinmetz PR, Raible F, Snyman H, Prud'homme B, Ferrier DE, Balavoine $G$, Arendt D: Molecular architecture of annelid nerve cord supports common origin of nervous system centralization in bilateria. Cell 2007, 129:277-288.

119. Martindale MQ, Pang K, Finnerty JR: Investigating the origins of triploblasty: 'mesodermal' gene expression in a diploblastic animal, the sea anemone Nematostella vectensis (phylum, Cnidaria; class, Anthozoa). Development 2004, 131:2463-2474.

120. Jekely G, Arendt D: Cellular resolution expression profiling using confocal detection of NBT/BCIP precipitate by reflection microscopy. Biotechniques 2007, 42:751-755.

121. TreeFam - database of animal gene trees. http://www.treefam.org.

122. Edgar RC: MUSCLE: multiple sequence alignment with high accuracy and high throughput. Nucleic Acids Res 2004, 32:1792-1797.

123. Castresana J: Selection of conserved blocks from multiple alignments for their use in phylogenetic analysis. Mol Biol Evol 2000, 17:540-552.

124. Abascal F, Zardoya R, Posada D: ProtTest: selection of best-fit models of protein evolution. Bioinformatics 2005, 21:2104-2105.

125. Tamura K, Peterson D, Peterson N, Stecher G, Nei M, Kumar S: MEGA5: molecular evolutionary genetics analysis using maximum likelihood, evolutionary distance, and maximum parsimony methods. Mol Biol Evol 2011, 28:2731-2739

126. Guindon S, Dufayard JF, Lefort V, Anisimova M, Hordijk W, Gascuel O: New algorithms and methods to estimate maximum-likelihood phylogenies: assessing the performance of PhyML 3.0. Syst Biol 2010, 59:307-321.

doi:10.1186/1741-7007-12-7

Cite this article as: Marlow et al.: Larval body patterning and apical organs are conserved in animal evolution. BMC Biology 2014 12:7.

\section{Submit your next manuscript to BioMed Central and take full advantage of:}

- Convenient online submission

- Thorough peer review

- No space constraints or color figure charges

- Immediate publication on acceptance

- Inclusion in PubMed, CAS, Scopus and Google Scholar

- Research which is freely available for redistribution 